\title{
Neuronal Plasminogen Activators: Cell Surface Binding Sites and Involvement in Neurite Outgrowth
}

\author{
Randall N. Pittman, Jonathan K. Ivins, and Helen M. Buettner \\ Department of Pharmacology, University of Pennsylvania School of Medicine, Philadelphia, Pennsylvania 19104
}

\begin{abstract}
Sympathetic neurons release both urokinase plasminogen activator (UPA) and tissue plasminogen activator (tPA). A number of inhibitors of serine proteases have been tested to determine their effects on neurite outgrowth from rat sympathetic neurons. Some inhibitors increase neurite outgrowth while others have little or no effect on outgrowth. Inhibition of plasminogen activator (PA) activity but not other serine protease activity correlates with the increase in neurite outgrowth (UPA, $r=0.89$; tPA, $r=0.86$; plasmin, $r=$ 0.015 ; thrombin, $r=0.025$ ). Antibodies that inhibit uPA activity increase neurite outgrowth, while antibodies that bind to uPA but do not inhibit activity do not alter outgrowth. Timelapse videomicroscopy of neurite outgrowth indicates that about $85 \%$ of the neurites increase their rate of outgrowth following exposure to inhibitors of PA. Routinely, 1-2 min after exposure of a growth cone to an inhibitor, there is an increase in lamellipodial activity at the leading edge of the growth cone and a decrease in lamellipodial activity on the sides and base of the growth cone. The increase in the rate of outgrowth combined with the decrease in lamellipodial activity on the sides of the growth cones results in neurites being very long and straight in the presence of inhibitors (persistence time $P=3.7$ and $15.3 \mathrm{hr}$ for controls and in the presence of inhibitors of PA, respectively).

PAs released from sympathetic neurons and PC12 cells interact with 3 different binding sites on the cell surface: (1) an inhibitor of serine proteases (including UPA and TPA) is bound to the surface via a heparinase-sensitive site; (2) a uPA-selective binding site is present in patches on the bottom surface of PC12 cells; and (3) a tPA-selective binding site with high affinity $\left(K_{\mathrm{D}}=23 \pm 10 \mathrm{nM}\right)$ and high capacity $\left(340,000 \pm 130,000\right.$ sites/neuron) for ${ }^{255}$-tPA is homogeneously distributed over the entire surface. Data in the present study are consistent with PA being involved in neurite outgrowth and open the possibility of other PA-dependent functions occurring when IPA and/or UPA interacts with cell surface binding sites.
\end{abstract}

A prominent feature of the developing nervous system is the extensive structural and cellular changes that occur over a short period of time. Few of the molecules responsible for these changes

\footnotetext{
Received Jan. 27, 1989; revised May 22, 1989; accepted June 13, 1989.

We thank Paulette Midgette for excellent technical assistance. This work was supported by NIH grant NS 22663 and a McKnight Scholars Award to R.N.P. J.K.I. was supported by a predoctoral fellowship from the Pharmaceutical Manufacturers' Association.

Correspondence should be addressed to Randall N. Pittman, Department of Pharmacology-6084, University of Pennsylvania School of Medicine, Philadelphia, PA 19104-6084.

Copyright (C) 1989 Society for Neuroscience $0270-6474 / 89 / 124269-18 \$ 02.00 / 0$
}

have been identified; however, the enzymatic activity associated with proteases makes them ideal candidates for producing many of the changes characteristic of the developing nervous system. Proteases may be involved in a variety of developmental events, including trophoblast implantation (Strickland et al., 1976; Glass et al., 1983), cell proliferation (Chen and Buchanan, 1975; Carney and Cunningham, 1977; Carney, 1987), differentiation (Ortolani et al., 1979; Cook et al., 1987), pattern formation (DeLotto and Spierer, 1986), and migration (Valinsky et al., 1981). In the nervous system, proteases have been implicated in plasticity (Lynch and Baudry, 1984), glial proliferation (Kalderon, 1984; Moonen et al., 1985), neural crest and granule cell migration (Moonen et al., 1982; Valinsky and LeDouarin, 1985; Grossman et al., 1987), neurotransmission (Baxter et al., 1983), and neurite outgrowth (Monard et al., 1983; Guenther et al., 1985; Hawkins and Seeds, 1986; Pittman and Patterson, 1987; Monard, 1988; Zurn et al., 1988).

Recent studies indicate that several proteases may be involved in cell motility and neurite outgrowth. At least 2 proteases are localized at focal adhesion plaques (dynamic cellular structures contacting the substratum that appear to be involved in motility). The calcium-dependent thiol protease CDP-II (also known as calpain II and CANP II) has been localized on the intracellular side of focal adhesion plaques in 3 different cell lines (Beckerle et al., 1987). A likely substrate for CDP-II at adhesion plaques is talin, a protein that helps link the intracellular cytoskeleton to cell surface extracellular matrix receptors (Burridge and Connell, 1983; Burridge and Mangeat, 1984; Horwitz et al., 1985). The localization of CDP-II at focal contacts and its ability to degrade talin makes it likely that CDP-II is involved in dynamic events associated with cell motility. The plasminogen activator (PA) urokinase (UPA) has also been localized to adhesion plaques. uPA is bound to a receptor on the external portion of adhesion plaques in HT 1080 human fibrosarcoma cells (Pollanen et al., 1987, 1988) and human fibroblasts (Pollanen et al., 1987; Hebert and Baker, 1988). uPA has a limited substrate profile; however, it can make cleavages in at least 3 molecules. uPA converts the inactive protease plasminogen into the active serine protease plasmin (Robbins et al., 1967); it makes limited cleavages in fibronectin (Quigley et al., 1987), and it cleaves a 66-kDa protein associated with the pericellular matrix (Keski-Oja and Vaheri, 1982). The presence of proteases on both the intracellular and extracellular sides of structures involved in cell motility is probably not fortuitous and may reflect the need to have enzymatically active molecules present at focal contacts to initiate cycles of adhesion and/or deadhesion required for cell motility and neurite outgrowth.

Proteases present on and released by growing neurites also appear to be involved in neurite outgrowth. Primary cultures 
of mouse sensory neurons and rat sympathetic neurons release PAs and a $\mathrm{Ca}^{2+}$-dependent metalloproteinase from distal processes and growth cones (Krystosek and Seeds, 1984; Pittman, 1985a). The $\mathrm{Ca}^{2+}$-dependent metalloproteinase released by growing neurites degrades native and denatured Type I collagen and is required for neurites to grow within 3-dimensional collagen matrices (Pittman and Williams, 1989). A thrombin-like serine protease released by (or present on) growing neurites has been implicated in neurite outgrowth from neuroblastoma cells (Monard et al., 1983; Gurwitz and Cunningham, 1988) and from primary cultures of mouse sensory ganglia (Hawkins and Seeds, 1986). In addition, glial and heart cell inhibitors of PA and thrombin increase neurite outgrowth from sympathetic neurons (Pittman and Patterson, 1987; Monard, 1988; Zurn et al., 1988). These observations are consistent with a neuronal PA and/or a neuronal thrombin-like protease being involved in neurite outgrowth. The present study was designed to investigate the role of PA in neurite outgrowth from rat sympathetic neurons. Preliminary reports of this work have appeared (Pittman, 1985b; Ivins et al., 1987; Pittman, 1988).

\section{Materials and Methods}

\section{Materials}

The following materials were obtained from Amcrican Diagnostica Inc., Greenwich, CT: monoclonal antibody (mAB) PAM-3, purified 1-chain human tissue plasminogen activator (tPA), and chromogenic protease substrates for uPA (Cbo-L-glu(t-BuO)-gly-arg-pNA.2AcOH), tPA $\left(\mathrm{CH}_{3} \mathrm{SO}_{2}\right.$-D-CHT-gly-arg-pNA.AcOH), plasmin (H-D-Nle-HHT-LyspNA. $2 \mathrm{AcOH}$ ), and thrombin (H-D-HHT, ala-arg-pNA.2AcOH). The following were obtained from Sigma Chemical Co., St. Louis, MO: leupeptin, soybean trypsin inhibitor, para-nitrophenylguanadinobenzoate (PNGB), human urokinase, diisopropylfluorophosphate (DFP), $p$-aminobenzamidine-Sepharose, thrombin, heparinase, and chondroitin ABC lyase. Aprotinin (trasylol) was obtained from Mobay Corp., New York, NY, and iodogen (1,3,4,6-tetrachloro-3a,6a-diphenylglycouril) was obtained from Pierce Chemical Co., Rockford, IL. Dansylglu-gly-arg-CMK and D-phe-pro-arg-CMK were obtained from Calbiochem, La Jolla, CA. Hi-fluorescein goat anti-mouse IgG and fluoresccin goat anti-rabbit IgG were obtained from Antibodies Inc., Davis, CA. Biotinylated rabbit anti-mouse IgG and streptavidin conjugated HRP were obtained from Zymed Laboratories, Inc., South San Francisco, CA. Fluoromount $\mathrm{G}$ was obtained from Fisher Scientific, Malvern, PA, and 1,4-diazabicyclo-(2,2,2)octane was obtained from Polysciences, Inc., Warrington, PA. Laminin was obtained from Collaborative Research Inc., Lexington, MA, and polyethyleneglycol 4000 and 6000 were obtained from VWR Scientific, Philadelphia, PA. Fetal calf and horse sera were obtained from Hyclone Laboratories, Inc., Logan, UT. Protein ASepharose CL-4B, lysine-Sepharose 4B, and AH-Sepharose 4B were obtained from Pharmacia, Piscataway, NJ.

\section{Cell culture}

Neurons from superior cervical ganglia of 2-3-day-old neonatal rats were mechanically dissociated and triturated using a 20-gauge needle. Sympathetic neurons were grown at $37^{\circ} \mathrm{C}$ in $5 \% \mathrm{CO}_{2}$ in $24-w e l l\left(2 \mathrm{~cm}^{2} /\right.$ well) tissue culture dishes coated with laminin $\left(1-2 \mu \mathrm{g} / \mathrm{cm}^{2}\right)$. The medium is a modification (Pittman, 1985a) of N2 medium (Bottenstein et al., 1980) and consists of $\mathrm{L} 15 \mathrm{CO}_{2}$ medium containing stable and fresh vitamins (Hawrot and Patterson, 1979), insulin $(5 \mu \mathrm{g} / \mathrm{ml})$, transferrin $(10 \mu \mathrm{g} / \mathrm{ml})$, selenium (30 nM), BSA $(100 \mu \mathrm{g} / \mathrm{ml})$, and 7S NGF $(200 \mathrm{ng} /$ $\mathrm{ml})$.

PC1 2 cells were grown in RPMI medium containing $10 \%$ horse serum and $5 \%$ fetal calf serum (Greene and Tischler, 1976). Serum-free medium used to grow $\mathrm{PC} 12$ cells is the same as that used for sympathetic neurons (see above). Prior to use of PC12 cells in experiments characterizing the neuronal inhibitor, cells were incubated for 16-24 hr in serum-free medium containing $2 \mathrm{mM}$ DFP or $25 \mu \mathrm{M}$ PNGB to irreversibly inactivate endogenous serine proteases. Crude membranes were prepared by homogenizing PC12 cells in $20 \mathrm{~mm}$ Tris containing $2 \mathrm{mM}$ DFP and then centrifuging at $13,000 \times g$ in a microfuge for $5 \mathrm{~min}$. The supernatant was discarded and the membrane pellet resuspended by trituration.

Neurite outgrowth parameters were obtained from sympathetic neurons that did not contact other neurons or non-neuronal cells. Neurons were grown on a laminin substrate in the absence of NGF for 12-18 hr in the absence or presence of protease inhibitors. Neurons were then fixed with PBS containing $2.5 \%$ glutaraldehyde. Neurite outgrowth data were obtained using a computer-based morphometry system consisting of a Nikon Diaphot microscope, Dage newvicon videocamera, IBM XT computer, Houston $\mathrm{Hi}$-pad, monitor, and a commercially available morphometry package (Southern Micro Instruments, Atlanta, GA). Reconstructions of neurite arbors in the presence and absence of the protease inhibitor dansyl-glu-gly-arg-CMK (GGA) were made by tracing cell bodies and neurites using a Houston Hi-pad digitizing tablet interfaced with an IBM XT computer followed by printing the traced image. Videomicroscopy was performed with a Nikon Diaphot microscope, Dage newvicon videocamera, and JVC BR $9000 U$ time lapse VCR. Images were taken from the VCR tapes using a Mitsubishi CP-100U video image printer.

Plasminogen was purified from rat serum according to the method of Deutsch and Mertz (1970), and NGF was purified from mouse saliva according to published procedures (Burton et al., 1978).

\section{Biochemistry}

Protease assays. Activities of serine proteases were determined by measuring the amount of para-nitroanalide released from chromogenic substrates. Reactions were carried out for $1-2 \mathrm{hr}$ at $37^{\circ} \mathrm{C}$ in a total volume of $0.15 \mathrm{ml}$ in 96-well radioimmunoassay (RIA) plates that had been preincubated with $1 \%$ gelatin (then washed extensively to block the binding of reaction components to the plate). Assays were stopped by adding $0.015 \mathrm{ml}$ acetic acid, and the amount of para-nitroanalide released was determined by measuring absorbance at $405 \mathrm{~nm}$. Routinely, 3 different concentrations of each protease and 4 different time points were assayed to assure linearity of the assay. IPA activity was assayed in $200 \mathrm{~mm}$ Tris-imidazole, $\mathrm{pH} 8.4$, containing $0.1 \%$ Triton $\mathrm{X}-100,100$ $1000 \mathrm{ng}$ of purified human tPA, and $2 \mathrm{mM} \mathrm{CH}_{3} \mathrm{SO}_{2}$-D-CHT-gly-argpNA.AcOH. Assay conditions for determining uPA activity were 50 mM Tris- $\mathrm{HCl}$, pH 9.0, containing $50 \mathrm{~mm} \mathrm{NaCl}, 0.1 \%$ PEG 6000, 100$1000 \mathrm{ng}$ low-molecular-weight human uPA, and $0.5 \mathrm{~mm}$ Cbo-L-glu(tBuO)-gly-arg-pNA.2AcOH. Plasmin activity was assayed in $50 \mathrm{~mm}$ Tris- $\mathrm{HCl}, \mathrm{pH} 7.4$, containing $0.1 \%$ Triton $\mathrm{X}-100,100-1000 \mathrm{ng}$ purified rat plasmin (formed by incubating plasminogen with $25 \mathrm{ng}$ of uPA at $37^{\circ} \mathrm{C}$ for $30 \mathrm{~min}$; this concentration of uPA did not degrade detectable levels of the plasmin substrate), and $0.3 \mathrm{~mm}$ H-D-Nle-HHT-LyspNA. $2 \mathrm{AcOH}$. Thrombin activity was determined in $20 \mathrm{~mm}$ Tris- $\mathrm{HCl}$, pH 7.8, containing $100 \mathrm{mM} \mathrm{NaCl}, 0.1 \%$ PEG 6000, 30-300 ng of purified human thrombin, and $0.5 \mathrm{~mm}$ H-D-HHT-ala-arg-pNA.2AcOH.

Protease gels. Protease gels were performed as previously described (Pittman, 1985a). In short, samples of medium from cultures of sympathetic neurons were electrophoresed in SDS buffer (Laemmli, 1970) at $9 \mathrm{~mA}$ and $4^{\circ} \mathrm{C}$ in polyacrylamide gels containing $7.3 \%$ acrylamide, $0.31 \%$ bisacrylamide, $0.11 \%$ gelatin, and $25 \mu \mathrm{g} / \mathrm{ml}$ rat plasminogen. Following extraction of SDS with $3 \times 15$ min washes of $2 \%$ Triton $\mathrm{X}-100$, gels were incubated in $20 \mathrm{~mm}$ Tris- $\mathrm{HCl}, \mathrm{pH} 8.0$, at $37^{\circ} \mathrm{C}$ for 14 hr. Gels were then fixed and stained with $0.2 \%$ coomassie. Proteases were visualized as clear bands against a background of dark-blue-staining gelatin.

Inhibitor gels. A modification of the procedure developed to detect inhibitors released from heart cells (Pittman and Patterson, 1987) was used in the present study. Serum-free conditioned medium from cultures of NGF-treated PC12 cells or membranes prepared from NGF-treated PC12 cells were mixed with SDS ( $2 \%$ final concentration) and electrophoresed in slab gels containing $7.3 \%$ acrylamide, $0.31 \%$ bisacrylamide, $0.11 \%$ gelatin, and $25 \mu \mathrm{g} / \mathrm{ml}$ plasminogen. Gels were electrophoresed at a constant current of $9 \mathrm{~mA}$ at $4^{\circ} \mathrm{C}$ in SDS buffer (Laemmli, 1970). SDS was removed following electrophoresis by washing gels $3 \times 15 \mathrm{~min}$ with 15 vol of $2 \%$ Triton X-100 while shaking. Gels were placed in 20 mM Tris, pH 7.5 , containing 2 units $/ \mathrm{ml} \mathrm{uPA}$ for $30 \mathrm{~min}$ at $22^{\circ} \mathrm{C}$, washed 4 times with buffer without uPA, and incubated for $6 \mathrm{hr}$ at $37^{\circ} \mathrm{C}$. Exposurc of gels to the solution containing uPA results in conversion of the plasminogen in the gel to plasmin, which in turn degrades the gelatin in the gel. Inhibitors of uPA block the activation of plasminogen by uPA in local areas of the gel and are visualized as bands of dark-blue gelatin in a clear gel following staining for protein with $0.2 \%$ coomassie. 
Complex formation between ${ }^{125} I-u P A$ and the neuronal inhibitor. Lowmolecular-weight human uPA was purified using a $p$-aminobenzamidine affinity column (Wun et al., 1982) to greater than $99 \%$ purity and iodinated with $\mathrm{Na}{ }^{125} \mathrm{I}$ using Iodogen. Sympathetic neurons were grown for 3-5 weeks in serum-free medium and PC12 cells were primed with NGF for 1 week in serum-containing medium and then subcultured and grown in serum-free medium for 5-10 d. Endogenous serine proteases present in cultures of sympathetic neurons and $\mathrm{PC1} 2$ cells were inactivated by incubating with $2 \mathrm{mM}$ DFP or $25 \mu \mathrm{M}$ PNGB for 16-24 $\mathrm{hr}$ prior to initiating experiments. Cells were incubated with ${ }^{125} \mathrm{I}-\mathrm{uPA}$ $\left(2 \times 10^{6} \mathrm{cpm} / \mathrm{ml} ; 5 \mathrm{nM}\right.$ final concentration) for $30 \mathrm{~min}$ in serum-free medium at $37^{\circ} \mathrm{C}$ and then washed twice with PBS, sonicated, boiled in sample buffer containing $4 \%$ mercaptoethanol and $2 \%$ SDS followed by SDS slab gel electrophoresis. Radiolabeled proteins were detected by autoradiography.

Release of the inhibitor from the cell surface. $\mathrm{PCl} 2$ cells were primed with NGF and grown in serum-free medium containing $2 \mathrm{mM}$ DFP to inactivate endogenous serine proteases. Cells were then washed 2 times with serum-free medium and fixed by drying in air. The cell surface inhibitor was labeled by incubating cells with $2 \times 10^{6} \mathrm{cpm}$ of ${ }^{125} \mathrm{I}-\mathrm{uPA}$ for $30 \mathrm{~min}$ at $37^{\circ} \mathrm{C}$. Cells were then washed extensively and incubated in PBS containing heparinase $(250 \mu \mathrm{g} / \mathrm{ml})$ or chrondroitin ABC lyase $(0.3$ units $/ \mathrm{ml})$ for $6 \mathrm{hr}$ at $37^{\circ} \mathrm{C}$. Incubation medium was removed from the cells and subjected to electrophoresis and autoradiography to determine the amount of the 68-kDa complex (representing the complex between the inhibitor and ${ }^{125}$ I-uPA) released from the cells. Quantitation was performed by slicing the gel in 2-mm segments and determining radioactivity in a gamma counter.

Blotting of the neuronal inhibitor. The method was essentially as previously described (Pittman and Patterson, 1987). Briefly, membranes from NGF-treated PC12 cells were solubilized in 2\% SDS and electrophoresed in $10 \%$ polyacrylamide gels at $4{ }^{\circ} \mathrm{C}$ and $9 \mathrm{~mA}$ using a Laemmli buffer system (Laemmli, 1970). Following electrophoresis, SDS was removed from the gel by incubating in $2 \%$ Triton X-100 for $1 \mathrm{hr}$ at $22^{\circ} \mathrm{C}$, followed by washing 4-5 times in buffer (10 mM Tris, $77 \mathrm{mM}$ glycinc, $\mathrm{pH}$ 8.3). Proteins were electrophoretically transferred onto 0.45 $\mu \mathrm{m}$ nitrocellulose sheets in ice-cold buffer (no methanol present) at 95 $\mathrm{V}$ for $40 \mathrm{~min}$. The nitrocellulose was cut into strips and incubated for $1 \mathrm{hr}$ in $20 \mathrm{~mm}$ Tris, pH 7.4, containing $150 \mathrm{~mm} \mathrm{NaCl}, 4 \mathrm{~mm}$ EDTA, and $0.1 \%$ Tween-20, to block nonspecific binding. Nitrocellulose strips were incubated for $6 \mathrm{hr}$ with gentle shaking in buffer containing $0.02 \%$ Tween-20 and $10^{6} \mathrm{cpm} / \mathrm{ml}{ }^{125}$ I-uPA. The nitrocellulose was then washed 4-5 times over a period of $1 \mathrm{hr}$ in buffer containing $0.02 \%$ Tween-20, followed by air drying and autoradiography.

Binding studies. Purified human tPA was iodinated to a specific activity of $140-190 \mathrm{Ci} / \mathrm{mmole}$ with $\mathrm{Na}^{125}$ I using chloramine $\mathrm{T}$. Binding studies with ${ }^{125}$ I-tPA were carried out on living or fixed cultures of sympathetic neurons or NGF-treated PC1 2 cells grown in 24-well cluster dishes $\left(2 \mathrm{~cm}^{2} /\right.$ well). Cells were fixed by rinsing 2 times with PBS (pH $7.5)$, incubating for $10 \mathrm{~min}$ at $4^{\circ} \mathrm{C}$ with $\mathrm{PBS}(\mathrm{pH} 3)$ to remove endogenous tPA bound to the receptor, rinsed 2 times with PBS ( $\mathrm{pH} 7.5$ ), and then air-dried. Briefly treating cultures with PBS, pH 3, routinely increased the number of binding sites $0-20 \%$, suggesting that only a small percentage of the tPA binding sites have endogenous tPA bound to them. Binding reactions were carried out in Hanks' buffered salt solution containing $2 \% \mathrm{BSA}$ for $120 \mathrm{~min}$ at $22^{\circ} \mathrm{C}$. Specific binding of ${ }^{125}$ I-tPA was defined as the amount of binding in the absence of competing ligand minus the amount of binding in the presence of $1.5 \mu \mathrm{M}$ unlabeled tPA. This concentration of unlabeled tPA was approximately 100 times its $K_{\mathrm{D}}$ value and corresponded to occupancy of approximately $99 \%$ of the receptors. Specific binding routinely represented $65 \%$ of total binding. Values for the number of receptors and affinity of receptors for 125I-tPA were determined for saturation isotherm data analyzed by the method of Scatchard (1949).

\section{Generation of antibodies}

Antisera against uPA were prepared by immunizing rabbits with 100 $\mu \mathrm{g}$ of purified human uPA cmulsificd in Freund's complete adjuvant, followed by boosting with $100 \mu \mathrm{g}$ of purified human uPA emulsified in Freund's incomplete adjuvant 4 weeks later. Serum was collected from the ear vein every 3 weeks for 15 weeks following the boost. Preimmune serum was collected from each rabbit prior to immunizations. In general, antisera made against human uPA only weakly cross-reacted with rat uPA. Antiserum was purified using Protein A-Sepharose followed by affinity purification using a uPA-Sepharose column (prepared by coupling purified uPA to activated AH-Sepharose $4 B$ ). A 2-step purification was performed because inhibitors in the rabbit serum bind to the active site of UPA and block the binding of antibodies directed against the active site (the majority of antibodies that cross-react with rat uPA bind at or near the active site). The affinity-purified antisera precipitated the uPA released by rat sympathetic neurons and inhibited the activity of the neuronal uPA. The affinity-purified antisera were further fractionated into those antibodies that bound to the active site and those that bound to other parts of the molecule. This was accomplished by chromatographing affinity-purified antibodies on a second uPA-Sepharose affinity column in which the active site of UPA had been irreversibly blocked with DFP. Antibodies that passed through the DFP-treated uPA-Sepharose column were those that bound at the active site (or those that bound to a region of the molecule whose conformation was sensitive to DFP binding to the active site, referred to as anti-uPA fraction \#2 in Fig. 5). Only $0.5 \%$ of the affinity-purified antibodies passed through the DFP-treated column; however, these were approximately 100 -fold more effective at inhibiting UPA activity than antibodies that bound to DFP-treated uPA-Sepharose (referred to as anti-uPA fraction \#1 in Fig. 5).

Hybridomas secreting monoclonal antibodies directed against tPA were generated by injecting female $\mathrm{Balb} / \mathrm{c}$ mice with $75 \mu \mathrm{g}$ of purified native human tPA in complete adjuvant followed by injection with 75 $\mu \mathrm{g}$ of heat-denatured human TPA in PBS $11 \mathrm{~d}$ later. Spleens were removed $3.5 \mathrm{~d}$ after the second injection and fused with SP-2 myeloma cells using PEG 4000 . Hybridoma supernatants were screened by RIA against purified human tPA. All positive clones from the first screen were screened against partially purified rat tPA using a dot blot RIA as well as by immunohistochemical assays using cultured neurons and Schwann cells. Over 100 hybridomas were obtained that secreted antibodies recognizing human $\mathrm{PAA}, 3$ of which also recognized rat tPA. Immunohistochemistry in the present study was performed with the IgG mAb 13E12. Similar results were obtained with IgG $\mathrm{mAbs} 2-1.2$ and $3-15$, as well as with a commercially available $\mathrm{mAb}$, PAM-3. Based on the ability of saturating concentrations of these mAbs to produce additive signals in RIAs, these $4 \mathrm{mAbs}$ appear to recognize 3 different epitopes on human tPA (and presumably rat tPA). None of these mAbs are useful for Western blots; therefore, we cannot rule out the possibility that 1 of the mAbs may cross-react with some other neuronal antigen. However, the chances that $4 \mathrm{mAbs}$ recognizing 3 different epitopes on tPA all cross-react with other neuronal antigens seems highly unlikely. The immunohistochemical staining, therefore, appears to represent authentic rat tPA. The IgG mAb 6-17, recognizing human tPA only, was used in some experiments to localize exogenously added tPA during binding reactions and as a negative control for experiments localizing rat $\mathrm{UPA}$ and $\mathrm{tPA}$.

\section{Immunohistochemistry}

Sympathetic neurons were grown in serum-free medium for $1-28 \mathrm{~d}$ in 24-well cluster dishes. Medium was removed from cultures, and the cells washed $2 \times 1 \mathrm{~min}$ with PBS and then fixed for $30 \mathrm{~min}$ in $50 \mathrm{~mm}$ phosphate buffer, pH 7.4, containing $4 \%$ paraformaldehyde. Cells were rinsed $3 \times 2 \mathrm{~min}$ and in some cases permeabilized for $3 \mathrm{~min}$ with icecold methanol : acetic acid (19:1) and then washed 5 times quickly. Cells were preincubated for $1 \mathrm{hr}$ at $22^{\circ} \mathrm{C}$ in PBS containing $0.3 \% \mathrm{BSA}, 3 \%$ serum (either rabbit or goat), and $0.2 \%$ Triton-X 100 (PBST). Triton was omitted from all buffers when immunohistochemical localization of cell surface antigens was performed. Hybridoma supernatants from 13E12,2-1.2, and 3-15 were diluted 1:1 with PBST, mAb PAM-3 was used at a concentration of $5 \mu \mathrm{g} / \mathrm{ml}$, and affinity-purified antiserum against human uPA was used at a concentration of $30-100 \mu \mathrm{g} / \mathrm{ml}$ (less that $1 \%$ of this antiserum bound to rat UPA). Incubations with primary antibodies were carried out at $22^{\circ} \mathrm{C}$ for $1.5 \mathrm{hr}$ followed by washing $3 \times 10$ min with PBST. Cells were then incubated with secondary antibody for $1 \mathrm{hr}$ at $22^{\circ} \mathrm{C}$ (either $\mathrm{Hi}$-fluorescein goat anti-mouse IgG or fluorescein goat anti-rabbit IgG or biotinylated rabbit anti-mouse IgG) followed by washing for $3 \times 15$ min with PBS containing $0.3 \%$ BSA (PBS/BSA). Fluorescently labeled cultures were viewed following mounting with Fluoromount $\mathrm{G}$ containing $2.5 \%$ final concentration 1,4-diazabicyclo$(2,2,2)$ octane using a Nikon microscope equipped for epifluorescence viewing. Cultures containing biotinylated secondary antibody were incubated for $45 \mathrm{~min}$ with streptavidin-conjugated HRP in PBS/BSA and then washed $3 \times 5 \mathrm{~min}$ with PBS/BSA, followed by incubation with $50 \mathrm{mM}$ Tris $-\mathrm{HCl}$ containing $0.05 \%$ diaminobenzidine- $\mathrm{HCl}$ and $0.01 \%$ 


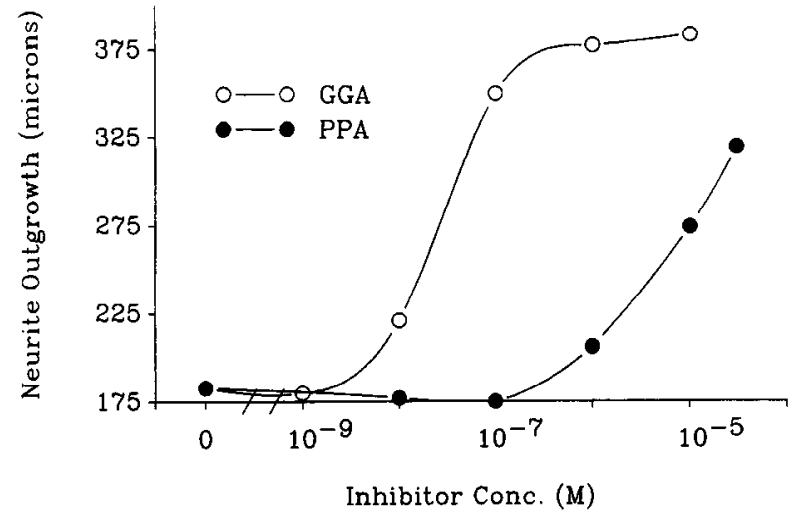

Figure 1. Effects of an inhibitor of PA-like serine proteases (GGA, $0-O)$, and an inhibitor of thrombin-like serine proteases (PPA, -0$)$ on neurite outgrowth. Sympathetic neurons were plated in the presence of various concentrations of the inhibitors for $14 \mathrm{hr}$ and then fixed and total neurite length/neuron measured. Each point represents the average total length of processes/neuron for 45-106 neurons obtained in two experiments.

$\mathrm{H}_{2} \mathrm{O}_{2}$. The cultures were visually inspected to monitor the development of the reaction, which was stopped by washing twice with PBS containing $0.02 \%$ sodium azide.

\section{Mathematical analysis}

Persistence times (a mathematical measure of how straight movement is, or a neurite in our case) were estimated using the method proposed by Dunn (1983) for characterizing the movement of whole cells bascd on the trajectories traced out by their centroids over a period of time. For the present study, the movement of interest was that of the growth cone centroid, the movement of which was assumed to be approximated by the neurite shape of fixed cells. Movement was assumed to have occurred at a constant rate on a time scale of hours. Thus, the distance moved in $1 \mathrm{hr}$ was given by:

$$
\frac{1}{n} \times \text { total neurite length }
$$

where $n$ represents the total number of hours during which outgrowth was allowed to occur. The root mean square displacement of the growth cone was estimated by dividing each neurite into $n$ nonoverlapping arc lengths and measuring the net (straight line) distance, $d_{i}$, between subsequent time points. The root mean square distance was then defined as:

$$
\left\langle d^{2}\right\rangle^{1 / 2}=\left[\frac{1}{n} \sum_{i=1}^{n} d_{i}^{2}\right]^{1 / 2}
$$

The reciprocal of this value was plotted against the reciprocal of the time interval to obtain the speed $(S)$ and persistence time $(P)$ from the relationship:

$$
\frac{1}{\left\langle d^{2}\right\rangle^{1 / 2}}=\frac{1}{s}\left[\frac{1}{t}+\frac{1}{6 P}\right]
$$

The slope of the line through the double reciprocal plot of $1 /\left\langle d^{2}\right\rangle^{1 / 2}$ vs $1 / t$ is equal to $1 / S$, and the intercept is equal to $1 / 6 S P$.

\section{Results}

Glial and heart cell inhibitors of thrombin and PA increase neurite outgrowth (Guenther et al., 1985; Pittman and Patterson, 1987; Gurwitz and Cunningham, 1988; Monard, 1988; Zurn et al., 1988); therefore, it is important to compare selective inhibitors of thrombin and PA for their ability to increase neu-

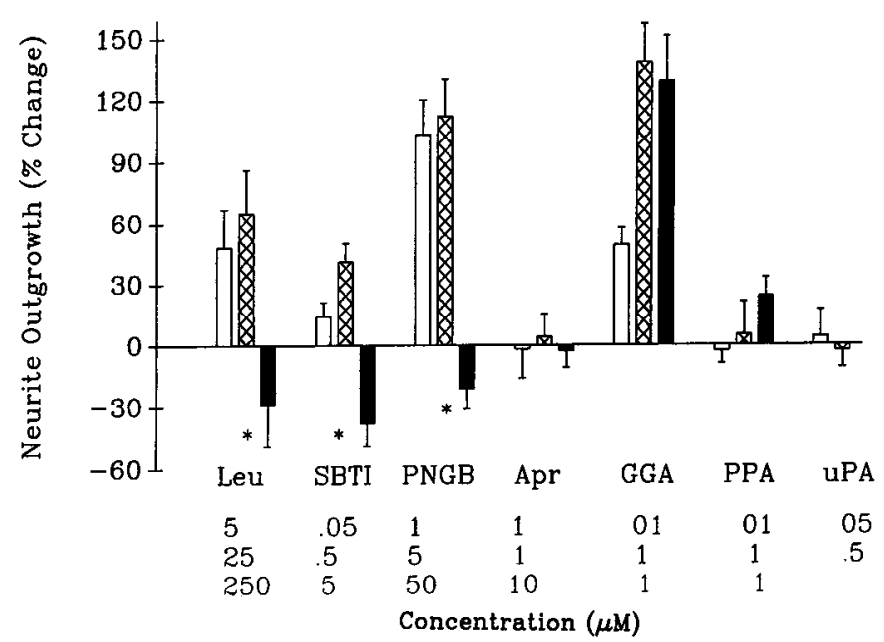

Figure 2. Effect of protease inhibitors and urokinase on neurite outgrowth. Sympathetic neurons were grown in the presence of leupeptin (Leu), soybean trypsin inhibitor (SBTI), para-nitrophenylguanadinobenzoate $(P N G B)$, aprotinin $(A p r)$, dansyl-glu-gly-arg-CMK $(G G A)$, D-phe-pro-arg-CMK (PPA), or purified human urokinase $(u P A)$ for 14-18 hr. Total neurite length/neuron was determined for 3 concentrations of each inhibitor (open bar represents data from the lowest concentration, hatched bar from the middle concentration, and solid bar the highest concentration of inhibitor). Each bar represents neurite outgrowth from $97-433$ neurons taken from 3-9 different experiments. Data are expressed as the percent change relative to controls (vehicle only) for each experiment and represent the mean \pm SEM of the average of individual experiments $(n=3-9)$. Asterisks $\left(^{*}\right)$ indicate toxic concentrations of inhibitors that are omitted from further analysis.

rite outgrowth. Neurite outgrowth from sympathetic neurons increases in a dose-dependent manner in the presence of an inhibitor of thrombin-like serine proteases (PPA; D-phe-proarg-CMK; Fig. 1) and in the presence of an inhibitor of PA-like serine proteases (GGA; dansyl-glu-gly-arg-CMK; Fig. 1). GGA is 100 times more effective at increasing neurite outgrowth from sympathetic neurons, which is consistent with PA being involved in neurite outgrowth.

To further test the possibility that PA is specifically involved in neurite outgrowth, sympathetic neurons were grown in the presence of a number of inhibitors of serine proteases. With the exception of leupeptin, all inhibitors tested (Fig. 2) inhibit only serine proteases. Leupeptin inhibits certain serine proteases (including PA), as well as calcium-dependent thiol proteases and lysosomal proteases (Umezawa and Aoyagi, 1977). Leupeptin is unusual in that it is the only inhibitor tested that increases the number of viable neurons in the cultures and the number of neurites per neuron (unpublished observations). A likely explanation for this is that by inhibiting lysosomal proteases, leupeptin allows neurons that are injured during the process of dissociating ganglia to survive self-autolysis. This would result in more neurons surviving. It is not obvious why neurons tend to have more neurites in the presence of leupeptin. It is clear, however, that leupeptin affects events other that neurite outgrowth. Therefore, the leupeptin data are not included in correlations of neurite outgrowth and inhibition of protease activity.

PNGB, a general inhibitor of serine proteases, increases neurite outgrowth at concentrations that effectively inhibit activity of the 4 serine protcases tested (Table 1; Fig. 2). At high concentrations ( $\geq 50 \mu \mathrm{M}$ ), PNGB is toxic to neurons as determined 


\begin{tabular}{|c|c|c|c|c|}
\hline \multirow{2}{*}{$\begin{array}{l}\text { Inhibitors } \\
\text { [Concen- } \\
\text { tration } \\
(\mu \mathrm{M})] \\
\end{array}$} & \multicolumn{4}{|c|}{$\begin{array}{c}\text { Proteases } \\
\text { (\% inhibition) }\end{array}$} \\
\hline & Thrombin & Plasmin & uPA & tPA \\
\hline \multicolumn{5}{|l|}{ SBTI } \\
\hline 0.05 & 0 & 104 & 11 & 18 \\
\hline 0.5 & 0 & 100 & 47 & 53 \\
\hline \multicolumn{5}{|l|}{ PNGB } \\
\hline 1 & 78 & 100 & 103 & 97 \\
\hline 5 & 101 & 98 & 102 & 100 \\
\hline \multicolumn{5}{|l|}{ Apr } \\
\hline 0.1 & 2 & 103 & 0 & 1 \\
\hline 1 & 0 & 97 & 3 & 3 \\
\hline 10 & 1 & 100 & 0 & 0 \\
\hline \multicolumn{5}{|l|}{ GGA } \\
\hline 0.01 & 0 & 0 & 49 & 58 \\
\hline 0.1 & 3 & 22 & 100 & 97 \\
\hline 1 & 18 & 58 & 104 & 101 \\
\hline \multicolumn{5}{|l|}{ PPA } \\
\hline 0.01 & 97 & 1 & 0 & 0 \\
\hline 0.1 & 99 & 14 & 7 & 0 \\
\hline 1 & 102 & 41 & 25 & 19 \\
\hline
\end{tabular}

Data are the average of 2 experiments performed in triplicate as described in Materials and Methods. uPA, urokinase; tPA, tissue plasminogen activator; SBTI, soybean trypsin inhibitor, PNGB, $p$-nitrophenylguanidinobenzoate; Apr, aprotinin; GGA, dansyl-glu-gly-arg-CMK; PPA, D-phe-pro-arg-CMK

by the presence of vacuoles in the cell bodies and the presence of "beaded" processes. High concentrations of PNGB, leupeptin, and soybean trypsin inhibitor (SBTI) are all toxic to neurons and are omitted from further analysis. The most effective inhibitor for increasing neurite outgrowth is GGA, while the plasmin inhibitor aprotinin (Apr) and the thrombin inhibitor PPA have little or no effect on neurite outgrowth at concentrations that completely inhibit plasmin and thrombin activity respectively (Table 1; Fig. 2). At the concentrations tested, purified human uPA does not affect neurite outgrowth from sympathetic neurons (Fig. 2). This is somewhat surprising in that it might be expected to decrease neurite outgrowth. This apparent inconsistency may be due to the high levels of uPA already present in these cultures (Fig. 4; inset, see also Pittman, 1985a), or to the observation that human uPA will not bind to the uPA "receptor-like" binding site on the neuronal surface (see Fig. 14 and Appendix).

Comparing the ability of agents to inhibit serine proteases (Table 1) with their ability to increase neurite outgrowth (Fig. 2) indicates that strong correlations exist between increasing neurite outgrowth and inhibiting the plasminogen activators tPA and uPA (Fig. 3), and poor correlations exist between increasing neurite outgrowth and inhibiting either thrombin or plasmin (Fig. 3). These data are consistent with PA having a function in neurite outgrowth; however, they do not distinguish between tPA and uPA.

In a previous study (Pittman, 1985a), it was determined that sympathetic neurons cultured for several weeks release uPA. The possibility that sympathetic neurons are also releasing tPA during the period when neurite outgrowth parameters are being measured in the present study (during the first $24 \mathrm{hr}$ of culture) was investigated. Immunohistochemical localization of tPA in-

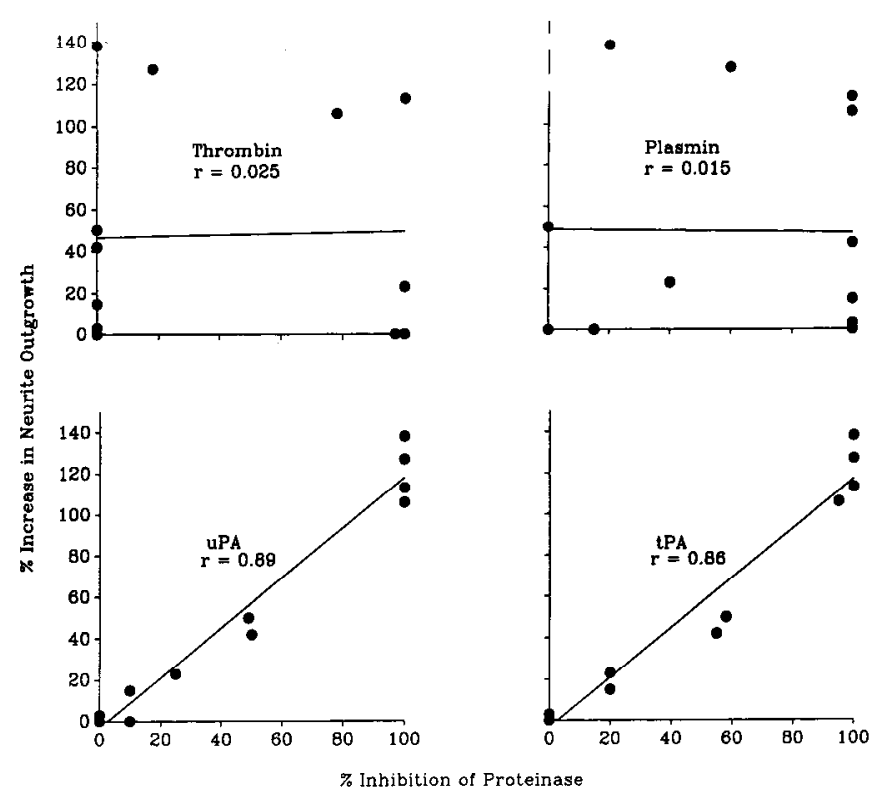

Figure 3. Correlation between the ability of serinc protcasc inhibitors to increase neurite outgrowth and to inhibit various serine proteases. Data are taken from Figure 2 and Table 1 for 5 different inhibitors (see Table 1 for inhibitors and concentrations).

dicates that sympathetic neurons in culture contain intracellular tPA immunoreactivity in their cell bodies, processes, and growth cones (Fig. 4). They exhibit immunohistochemical staining for tPA on day 1 in culture and maintain this intracellular tPA immunoreactivity at least 4 weeks in culture (data not shown). During the first 2-3 d in culture, a small amount of tPA is also present in the culture medium (Fig. $4 A$, inset). Thereafter, either tPA is not released, or the amount of tPA released is below the level of detection.

Not only do sympathetic neurons release both uPA and tPA (Fig. 4, inset) during the period when inhibitors of serine proteases increase neurite outgrowth (during the first $24 \mathrm{hr}$ of culture), but equally strong correlations also exist for inhibiting tPA or uPA activity and increasing neurite outgrowth (Fig. 3). Since inhibitors do not effectively distinguish between tPA and uPA, antibodies were used to differentiate between them. None of the mAbs that recognize rat tPA inhibit its activity, and preliminary experiments indicate that these antibodies do not affect neurite outgrowth (data not shown). Therefore, the effect of selectively inhibiting tPA is unknown. An affinity-purified antiserum against uPA, however, does inhibit activity and increase neurite outgrowth (Fig. 5). Antibodies that bind at or near the active site and inhibit uPA activity increase neurite outgrowth (Fig. 5, fraction \#2) while antibodies that bind to other parts of UPA and do not inhibit activity do not increase neurite outgrowth (Fig. 5, fraction \#1). These data indicate that at least part of the increase in neurite outgrowth following treatment of sympathetic neurons with inhibitors of serine proteases probably results from inhibition of uPA activity. Routinely, maximally effective concentrations of inhibitors of PA such as GGA increase neurite outgrowth $120-130 \%$ (Fig. 2). Antibodies that completely inhibit uPA activity, however, increase neurite outgrowth only $75 \%$. This may indicate that part of the increase in neurite outgrowth following treatment of neurons with inhibitors of serine proteases is due to inhibition of other PA-like serine proteases, possibly tPA. 
Figure 4. Immunohistochemical localization of intracellular tPA in cultured sympathetic neurons and the release of tPA and UPA from cultures of sympathetic neurons. Immunohistochemical localization of intracellular tPA $(A)$ was performed on neurons grown in culture for $10 \mathrm{~d}$ and permeabilized with methanol/acetic acid and Triton X-100. mAb 13E12 was used as the primary antibody (similar staining was obtained with mAbs 2-1.2, 3-15, and PAM-3). Solid arrows indicate immunohistochemical staining that extends into growth cones of 3 neurites and open arrows point to fibroblast-like cells that are not staining. A phase contrast micrograph $(B)$ of the negative control $(C ; \mathrm{mAb}$ 6-17 that recognizes only human tPA) is shown for comparison. No HRP reaction product is visible in the control. The inset in $A$ is a protease gel (see Materials and Methods) showing the presence of small quantities of tPA in the culture medium $24 \mathrm{hr}$ after plating, but the absence of tPA in the medium after $7 \mathrm{~d}$. UPA is present in the medium after $1 \mathrm{~d}$ and $7 \mathrm{~d}$. Samples represent $3 \%$ of the proteases released during a 24-hr period.
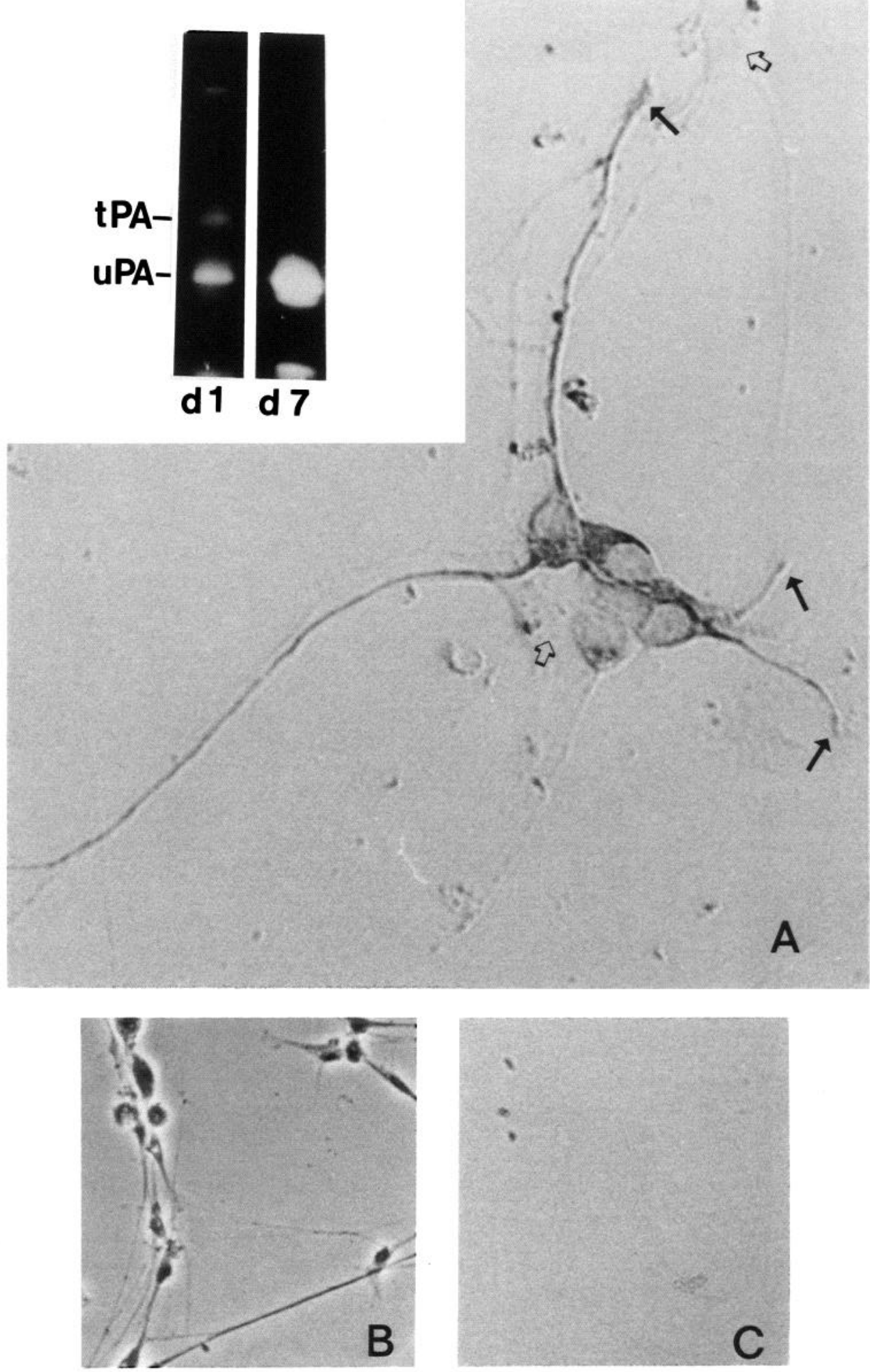

Neurites are not only longer following inhibition of PA, but are also much straighter than control neurites (Fig. 6). This is reflected in a 4-fold increase in the persistence time for neurons treated with $1 \mu \mathrm{M}$ GGA (control, $P=3.7 \mathrm{hr}$; GGA, $P=15.3$ $\mathrm{hr}$ ). Persistence time is a measure of tortuosity and is an indication of the amount of time a growth cone spends "wandering around" the culture dish in contrast to growing straight. The higher the persistence time, the straighter the neurite.

Acute effects of GGA on growth cone motility can be observed using time-lapse videomicroscopy (Fig. 7). The most obvious change in the growth cone following the addition of GGA, other than the increase in the rate of outgrowth, is in membrane 


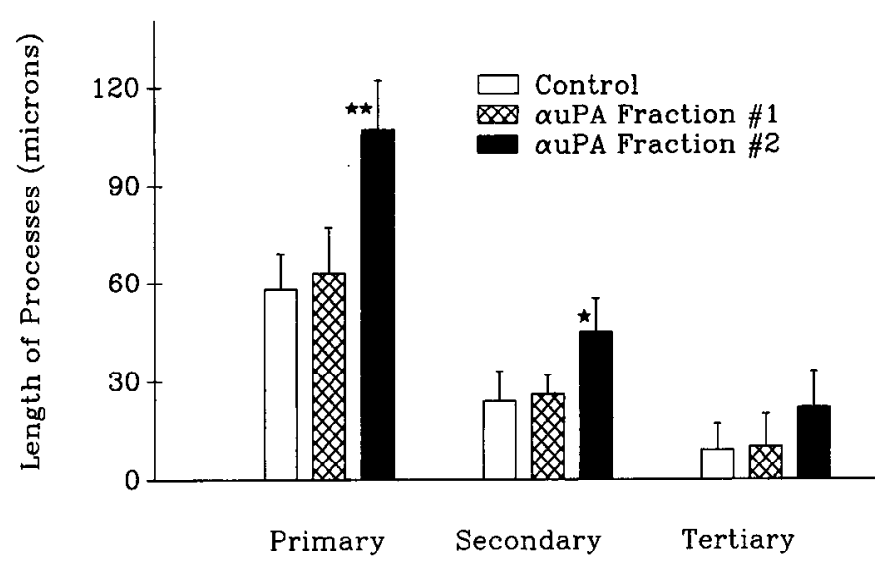

PROCESS TYPE

Figure 5. Neurite outgrowth in the presence of antiserum directed against uPA. Sympathetic neurons were grown for $14 \mathrm{hr}$ in the presence of $5 \mu \mathrm{g} / \mathrm{ml}$ preimmune IgG (control), or affinity-purified antiuPA antibodies that bind at or near the active site of uPA (anti-uPA Fraction \#2), or to other parts of the molecule (anti-uPA Fraction $\# 1$ ). Primary processes are neurites growing out from the cell body, secondary processes branch from primary neurites, and tertiary processes branch from secondary neurites. Data represent the mean \pm SEM of neurite lengths from 118 (control), 158 (anti-uPA Fraction $\# 1$ ), and 141 (anti-uPA Fraction \#2) neurons. * $p<0.05 ; * * p<0.005$ compared to anti-uPA Fraction \#1 and control values.

ruffling and lamellipodial activity. Prior to addition of GGA, growth cones are often triangular or diamond-shaped and lamellipodial activity and membrane ruffling are present around the circumference of the growth cone (Fig. 7, $A-F$ ). For instance, the top arrows in Figure 7, $B, C$, and $D$ show the expansion and collapse of membrane on the side of the growth cone that eventually gives rise to a large filopodium, whereas the bottom arrows in Figure 7, $C, D$ show a lamellipodium retracting at the base of the growth cone. The arrow in Figure $7 E$ points out an extending lamellipodium. Following addition of GGA, the growth cone often becomes more elongated and lamellipodial activity is primarily, although not exclusively, restricted to the leading edge of the growth cone (Fig. 7, G-L). Arrows in Figure 7, $H$ and $I$, show an extending lamellipodium at the leading edge and the arrows in $K$ (upper arrow) and $L$ point to filopodia forming at the leading edge. The lower arrow in $K$ shows a withdrawing lamellipodium. The decrease in lamellipodial activity on the sides of the growth cone along with the increase in activity at the leading edge apparently decreases "wandering around" the dish and produces straighter and longer neurites. Approximately $85 \%$ of the growth cones increase their rate of outgrowth (40$250 \%$ increases in rates) following exposure to GGA (Fig. 8). Routinely, increases in rates of outgrowth are obvious within 1-2 min following addition of GGA.

\section{Cell surface binding sites}

The studies described above demonstrate that inhibitors of PA alter growth cone dynamics and increase neurite outgrowth. This suggests that PA is involved in specific aspects of neurite outgrowth. Studies were initiated, therefore, to examine the mechanism of PA involvement in neurite outgrowth. As an initial experiment, the fate of $P A$ released by neurons was investigated by incubating cultures with tracer quantities of ${ }^{125} \mathrm{I}$-uPA or ${ }^{125} \mathrm{I}$ tPA, and the disposition of the labeled PA followed. Incubation of sympathetic neurons with ${ }^{125} \mathrm{I}-\mathrm{uPA}$ shows that a protein is present on the surface of neurons that binds uPA extremely tightly (probably irreversibly; the complex between ${ }^{125}$ I-uPA and the surface protein is stable in boiling $\mathrm{SDS} /$ mercaptoethanol). The complex between ${ }^{125} \mathrm{I}$-uPA (MW of $33 \mathrm{kDa}$ ) and the surface protein has an apparent molecular weight of $68 \mathrm{kDa}$ (Fig. 9, lane 2), and the complex does not form in the absence of cells (Fig. 9, lane 1). Two additional experiments indicate that the active site of uPA is probably involved in the interaction with the neuronal protein: (1) active site inhibitors of UPA (DFP and
A

A

$$
\text { ? }
$$<smiles>CCCCCC</smiles><smiles>CCCC</smiles><smiles>CCCC</smiles><smiles>CCCCC</smiles><smiles>C1CCC1</smiles><smiles>[CH]1CC1</smiles><smiles>[Te][Te]</smiles>

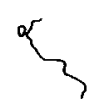<smiles>CC1CC1</smiles><smiles>C=C(C)C</smiles><smiles>CCCCC</smiles><smiles></smiles><smiles>CC1=CC(C)CC1</smiles>

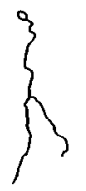

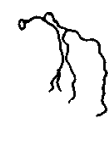<smiles>[Tl][Tl]</smiles><smiles>C1CCC1</smiles><smiles>[B]C</smiles><smiles>CCCC</smiles><smiles>CCCCC</smiles><smiles>C=CCCCCCCCC</smiles><smiles>C=CC(C)=C(C)C</smiles><smiles>CCCC(C)CC</smiles><smiles>CCCCC</smiles><smiles>CCCC[Te]</smiles><smiles>CCC(C)CC</smiles><smiles>CCC(C)CC(C)CC(C)CC(C)C(C)C</smiles>

Figure 6. Reconstruction of neurite arbors in the absence $(A)$ or presence $(B)$ of GGA. Neurons were grown for $14 \mathrm{hr}$ in the absence or presence of 1 $\mu \mathrm{M}$ GGA and tracings made as described in Materials and Methods. Note that in the presence of GGA, neurites are not only longer, but are also much straighter. 

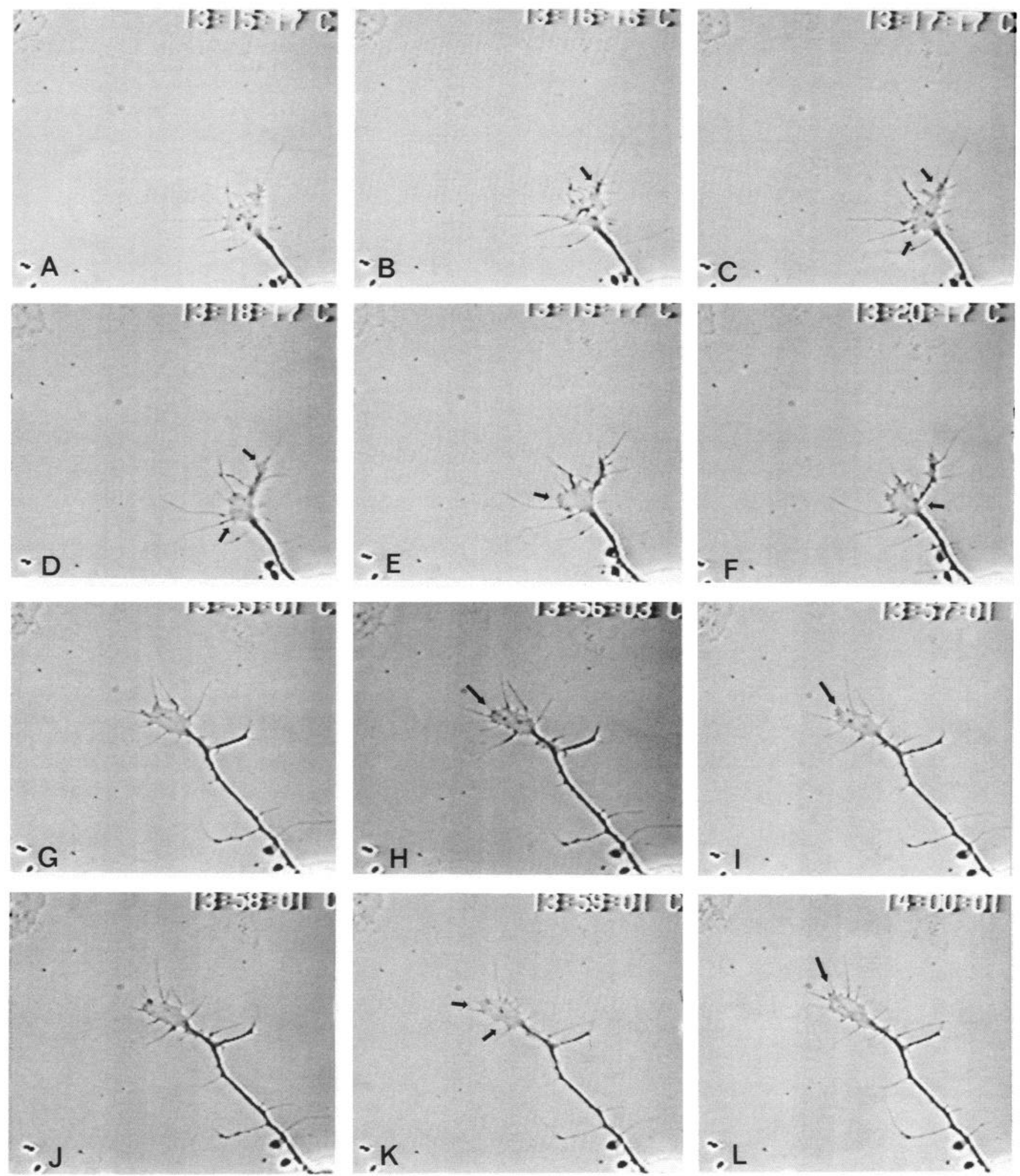

Figure 7. Video images of a growth cone prior to and following addition of GGA. Images in $A-F$ are at 1 -min intervals prior to addition of GGA. Neurite outgrowth rate is $29 \mu \mathrm{m} / \mathrm{hr}$ and active membrane protrusions and withdrawals are present around the circumference of the growth cone. Arrows indicate areas of membrane activity during the previous or subsequent 1-min period (see text for description). Addition of GGA $(0.5 \mu \mathrm{M}$ final concentration) at 13:45:00 increases the rate of outgrowth to $57 \mu \mathrm{m} / \mathrm{hr}(G-L)$. Following addition of GGA, most of the membrane activity is at the leading edge of the growth cone (arrows) and not on the sides or base of the growth cone. Note also the change in shape of the growth cone following GGA. 

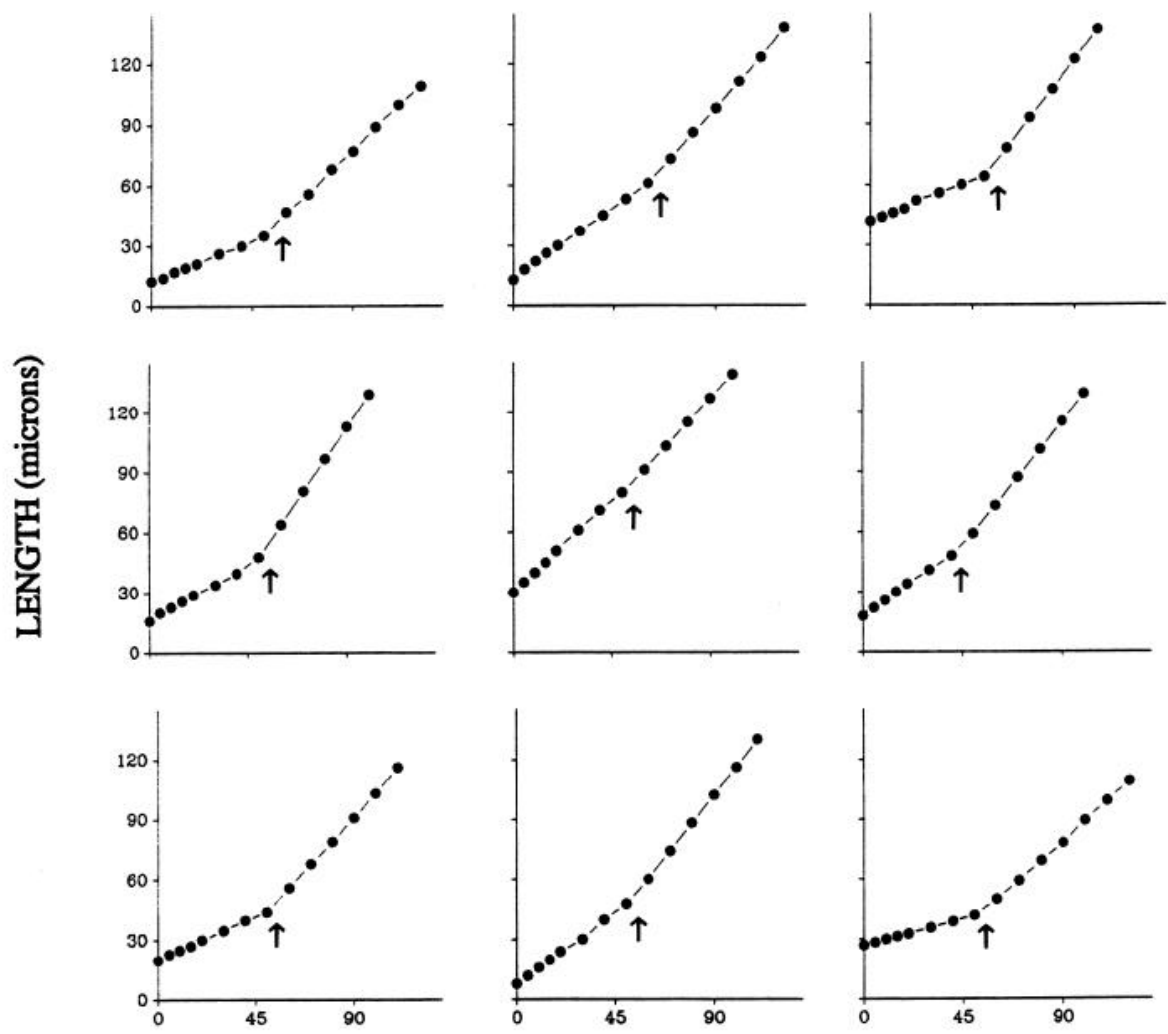

TIME (mins)
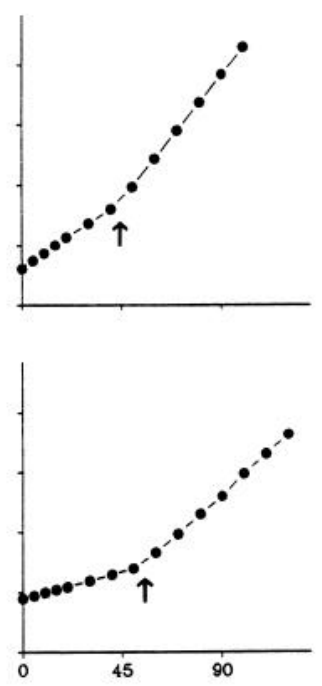

Figure 8. Changes in rates of neurite outgrowth following addition of GGA to the culture medium. Data are taken from time-lapse video recordings similar to those shown in Figure 7. Arrows indicate the addition of GGA $(1 \mu \mathrm{M}$ final concentration). The length of the neurite relative to a fixed point in the culture (routinely the cell body) was measured every 5 or $10 \mathrm{~min}$.
PNGB) block the formation of the complex between ${ }^{125} \mathrm{I}-\mathrm{uPA}$ and the surface protein, and (2) gel electrophoresis assays for proteolytic activity indicate that uPA activity is present at 33 $\mathrm{kDa}$ (representing ${ }^{125} \mathrm{I}-\mathrm{uPA}$ ) and at $51 \mathrm{kDa}$ (representing endogenous uPA), but no uPA activity is present at $68 \mathrm{kDa}$ (data not shown). Based on its ability to form an extremely tight complex with the active site of uPA, and its apparent ability to inhibit uPA proteolytic activity, it is likely that the neuronal protein represents an inhibitor of serine proteases.

The amount of this inhibitor protein present on sympathetic neurons is insufficient to begin biochemical characterization; however, NGF-treated PC1 2 cells have a protein on their surface that forms a $68-\mathrm{kDa}$ complex with ${ }^{125} \mathrm{I}-\mathrm{uPA}$ (Fig. 10, lane 1). As is the case with sympathetic neurons, active site inhibitors of uPA block the formation of the $68-\mathrm{kDa}$ complex (Fig. 10, lane 2). Based on identical molecular weights of complexes with ${ }^{125} \mathrm{I}-\mathrm{uPA}$, the stability of the complexes in boiling SDS/mercaptoethanol, and the requirement of the active site of uPA in complex formation, it is likely that the proteins on sympathetic neurons and PC12 cells are identical or very similar. Although PC1 2 cells do not contain a large number of molecules of the inhibitor, sufficiently large numbers of cells can be grown to determine some of its properties. The molecular weight of the protein on PC12 cells can be determined by solubilizing membranes from NGF-treated PC12 cells followed by SDS polyacrylamide gel electrophoresis and blotting onto nitrocellulose. When nitrocellulose is "probed" with ${ }^{125} \mathrm{I}-\mathrm{uPA}$, a single protein of $50 \mathrm{kDa}$ is detected (Fig. 11). Gel electrophoresis assays for inhibitors performed on membrane preparations from NGFtreated PC12 cells indicate that an inhibitor with a molecular

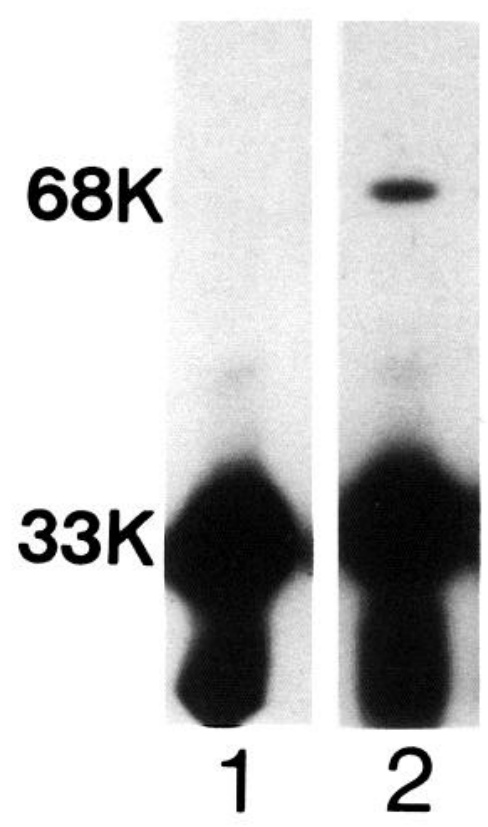

Figure 9. Complex formed between a protein present on sympathetic neurons and ${ }^{125}$ I-uPA. Cultured sympathetic neurons (lane 2) or a control culture well containing no cells (lane 1) were incubated with ${ }^{125} \mathrm{I}$-uPA for $20 \mathrm{~min}$ at $37^{\circ} \mathrm{C}$ followed by rinsing quickly with PBS, sonicating, boiling in SDS/mercaptoethanol, electrophoresis, and autoradiography. The band at $68 \mathrm{kDa}$ represents the complex between the neuronal protein and ${ }^{125} \mathrm{I}-\mathrm{uPA}$, the band at $33 \mathrm{kDa}$ is ${ }^{125} \mathrm{I}-\mathrm{uPA}$, and the band below this is a breakdown product of UPA resulting from boiling in SDS. 


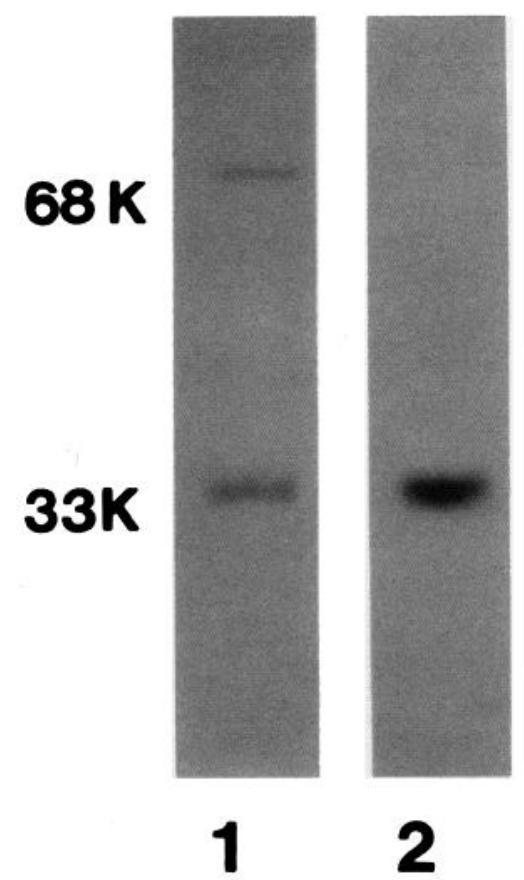

Figure 10. Complex formed between a protein on $\mathrm{PC} 12$ cells and ${ }^{125}$ I-uPA. NGF-treated PC12 cells (ca. $2 \times 10^{5}$ ) were incubated with ${ }^{125} \mathrm{I}$-uPA in the absence (lane 1) or presence of $2 \mathrm{mM}$ DFP (lane 2) and processed as described in Figure 9. Note that the complex $\left(M_{t}\right.$ $68 \mathrm{kDa}$ ) between ${ }^{125} \mathrm{I}-\mathrm{uPA}$ (MW $33 \mathrm{kDa}$ ) and the PC12 protein is not present if the active site of ${ }^{125} \mathrm{I}$-uPA is irreversibly blocked with DFP.

weight of approximately $50 \mathrm{kDa}$ is present (Fig. 12, lane 1). This same inhibitor can be detected in conditioned medium from $\mathrm{PC} 12$ cells and therefore appears to be released from PC12 cells (Fig. 12, lane 2). It seems likely that this $50-\mathrm{kDa}$ inhibitor is the same protein present on sympathetic neurons and PC12 cells that binds to the active site of uPA. The discrepancy between the molecular weight of the complex $(68 \mathrm{kDa})$ and the individual components $(33 \mathrm{kDa}$ for $\mathrm{uPa}$ and $50 \mathrm{kDa}$ for the cell surface inhibitor protein) may be due to an anomalous rate of migration for the complex during polyacrylamide gel electrophoresis, although a more likely possibility is that a $10-12-\mathrm{kDa}$ piece of the inhibitor is cleaved during complex formation. This has been shown to occur for interactions between other cellular inhibitors and serine proteases (Johnson and Travis, 1976; Chandra and Bang, 1977; Scott and Baker, 1983). If this is the case, then a molecular weight of approximately $71-73 \mathrm{kDa}$ would be predicted for the complex between uPA and the neuronal inhibitor, which is in good agreement with the $68-\mathrm{kDa}$ complex observed in our studies.

Initial experiments indicate that the neuronal inhibitor is not removed from the cell surface or membrane preparations by extensive washes with isotonic buffers, but variable amounts are removed with hypertonic and hypotonic buffers. Most of the inhibitor, however, is released from PC12 cells with heparinase but not with chondroitinase (Fig. 13). This suggests that the inhibitor is not an integral membrane protein, but rather binds to the cell surface through an interaction with heparan sulfate proteoglycan.

Attempts to localize the inhibitor indirectly by localizing DFPsensitive binding of uPA to the cell surface have not been successful thus far; however, during these experiments, it became

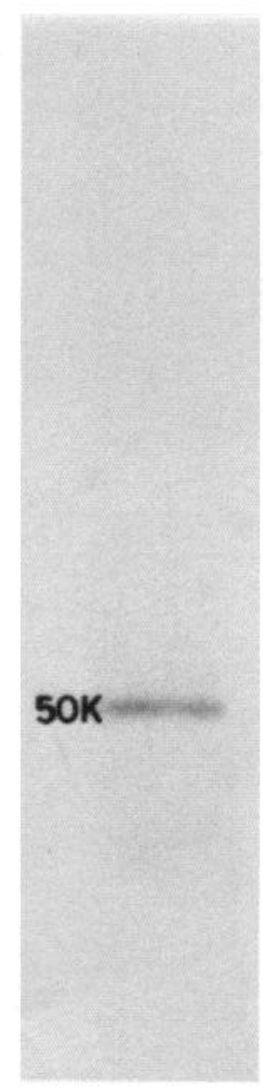

Figure 11. Protein on NGF-treated PC12 cells that binds ${ }^{125} \mathrm{I}$-uPA Membranes from PC12 cells were solubilized in 2\% SDS, electrophoresed in a polyacrylamide gel, and transferred onto nitrocellulose. The nitrocellulose was probed with ${ }^{125}$ I-uPA followed by autoradiog raphy. The band at $50 \mathrm{kDa}$ represents a protein present on $\mathrm{PC} 12$ cells that binds ${ }^{125} \mathrm{I}-\mathrm{uPA}$.

evident that another binding site for uPA is present on PC12 cells and sympathetic neurons. This second binding site for uPA can be detected by immunohistochemical localization of uPA in the presence of active site inhibitors (DFP or PNGB) that block the interaction of UPA and the neuronal inhibitor. This second binding site for UPA is present in patches on the bottom surface of cells at the level of the substrate (Fig. 14). It is likely that uPA bound to this site represents the "spots" of proteolytically active PA present on the substrate following removal of cultured sensory (Krystosek and Seeds, 1986) and sympathetic (R. N. Pittman, unpublished observations) neurons. Preincubation of $\mathrm{PC} 12$ cells with excess plasminogen, tPA, or thrombin does not alter the immunohistochemical staining pattern (not shown), suggesting that the binding site is selective for uPA. Neither high- nor low-molecular-weight human ${ }^{125}$ I-uPA appears to interact with this uPA binding site; therefore, further pharmacological and biochemical characterization will depend on purification of rat $\mathrm{UPA}$ and generation of good immunological probes against rat $\mathrm{uPA}$.

Incubation of cells with tracer amounts of ${ }^{125}$ I-tPA indicates that sympathetic neurons and $\mathrm{PC} 12$ cells have a binding site on their surface for tPA. Unlike the "receptor-like". binding site for UPA, which appears to be specific for rat uPA, the "receptorlike" binding site for tPA also binds human tPA (Fig. 15). At $22^{\circ} \mathrm{C}$, binding reaches equilibrium after about $120 \mathrm{~min}$, and upon addition of a 100 -fold excess of unlabeled tPA, the binding 


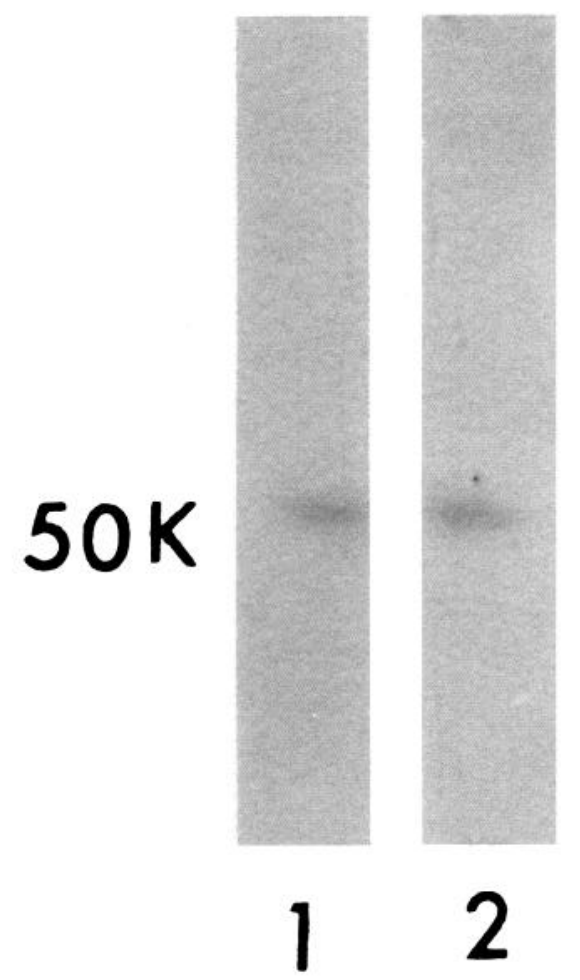

Figure 12. Inhibitor of PA present on and released by NGF-treated PC12 cells. Membranes (lane 1) from PC12 cells and serum-free conditioned medium from cultures of $\mathrm{PC} 12$ cells (lane 2) were electrophoresed in a polyacrylamide gel containing gelatin and plasminogen. Following electrophoresis, the gel was incubated in a solution containing 2 units $/ \mathrm{ml} \mathrm{uPA}$, which activates the plasminogen in the gel. The plasmin then degraded proteins in the gel (either gelatin or PC12 proteins). Inhibitors of PA (or plasmin) are detected as bands of gelatin remaining in the gel following staining for protein with coomassie. The bands at $50 \mathrm{kDa}$ represent gelatin that is not degraded by uPA-activated plasmin.

of ${ }^{125} \mathrm{I}$-tPA is readily reversible (Fig. 15 ). The association rate constant $\left(k_{1}\right)$ is $3.1 \pm 1.1 \times 10^{5} \mathrm{M}^{-1} \min ^{-1}(n=3)$, and the dissociation rate constant $\left(k_{-1}\right)$ is $6.3 \pm 0.3 \times 10^{-3} \mathrm{~min}^{-1}(n=$ 3). Saturation isotherms of ${ }^{125} \mathrm{I}$-tPA binding demonstrate a highaffinity, saturable binding site on sympathetic neurons (Fig. 16) and on PC1 2 cells (not shown). Scatchard analysis of the binding of ${ }^{125}$ I-tPA to sympathetic neurons (Fig. 17) indicates that there are $340,000 \pm 130,000(n=7)$ binding sites/neuron with a $K_{\mathrm{D}}$ $=23 \pm 10 \mathrm{nM}(n=7)$. The active site of tPA is probably not involved in the binding reaction in that binding parameters are not altered in the presence of an active site inhibitor of tPA (Fig. 17, filled circles are in the presence of $2 \mathrm{~mm} \mathrm{DFP).}$

${ }^{125} \mathrm{I}$-tPA bound to neuronal cultures can be visualized by performing autoradiography or immunohistochemistry (immunohistochemistry provides a more precise location compared to ${ }^{125}$ I autoradiography). Immunohistochemical localization of human tPA bound to cultures of sympathetic neurons following an equilibrium binding reaction shows that tPA binds to the entire surface of neurons, but little or none binds to the laminin substrate (Fig. 18). It has been reported that tPA "binds" to laminin (Salonen et al., 1984); however, under the conditions we use to perform our binding assays, we do not obtain specific binding of ${ }^{125} \mathrm{I}$-tPA to the laminin substrate in the absence of neurons (binding data not shown). The binding of ${ }^{125}$ I-tPA to

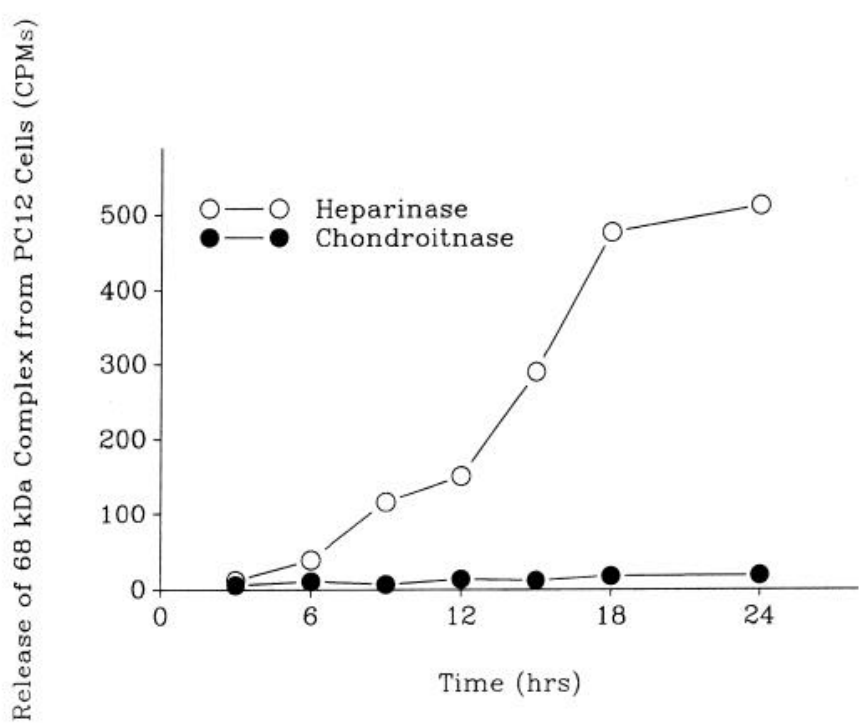

Figure 13. Release of the protein that forms a $68-\mathrm{kDa}$ complex with ${ }^{125}$ I-uPA from PC12 cells with heparinase. Fixed PC12 cells were incubated with ${ }^{125} \mathrm{I}$-uPA, washed extensively, and then incubated with heparinase $(\mathrm{O}-\mathrm{O})$ or chondroitinase $(-)$ for $6 \mathrm{hr}$ at $37^{\circ} \mathrm{C}$. The amount of $68-\mathrm{kDa}$ complex released into the medium was determined by electrophoresis of the medium, slicing the gel into 2-mm segments, and determining radioactivity in a gamma counter. Background counts (incubation in buffer alone) are subtracted from values.

sympathetic neurons is not inhibited effectively by other serine proteases (Fig. 19) or by a variety of other agents including NGF, EGF, insulin, antibodies against fibronectin, or a panel of mAbs against the neuronal cell surface (not shown). Therefore, the binding appears to be a selective interaction between tPA and a specific component on the neuronal surface that recognizes tPA but not other serine proteases tested. The properties of all 3 PA binding sites present on sympathetic neurons and $\mathrm{PC} 12$ cells are summarized in the Appendix.

\section{Discussion}

Proteases are released by a variety of neuronal and glial cells from the central and peripheral nervous systems (Krystosek and Seeds, 1981a, 1984; Soreq and Miskin, 1981, 1983; Moonen et al., 1982, 1985; Kalderon, 1984; Alvarez-Buylla and Valinsky, 1985; Pittman, 1985a; Valinsky and LeDouarin, 1985). Neurons release both serine proteases and metalloproteases from distal processes and growth cones (Krystosek and Seeds, 1981b, 1984; Pittman, 1985a). These observations are consistent with proteases being involved in functions associated with growth cones, such as neurite outgrowth, pathfinding, target recognition, and synaptogenesis. One obvious function for proteases released by growth cones would be to create "channels" in the ECM through which neurites could grow. This appears to be the function of a $\mathrm{Ca}^{2+}$-dependent metalloproteinase released by sensory and sympathetic neurons of the peripheral nervous system (Pittman, 1985a; Pittman and Williams, 1989). Inhibition of the neuronal metalloproteinase activity blocks neurite penetration and outgrowth in 3-dimensional collagen gels (Pittman and Williams, 1989). The function of the neuronal PAs, however, is less clearly defined than that of the $\mathrm{Ca}^{2+}$-dependent metalloproteinase.

In general, the physiological functions of PAs are more speculative than definitive. A number of indirect studies are con- 

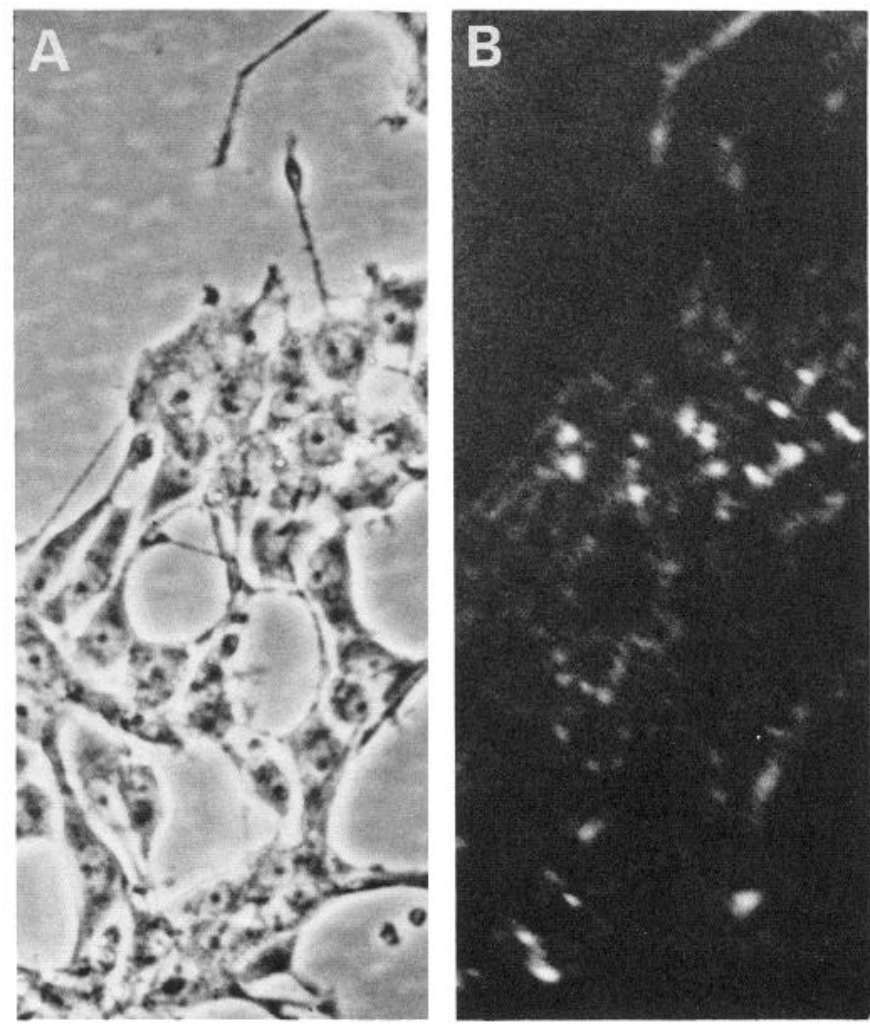

Figure 14. Immunohistochemical localization of uPA bound to the cell surface of PC12 cells. PC12 cells were treated with NGF for $5 \mathrm{~d}$, fixed, and processed for immunohistochemistry. For $48 \mathrm{hr}$ prior to fixing (days 3-5), the cells were incubated with 2 mM DFP (fresh DFP added every $12 \mathrm{hr}$ ) to block the finding of uPA to the cell surface inhibitor (see Figs. 9-12). The plane of focus for the phase photomicrograph $(A)$ is on the top surface of the PC12 cells and the plane of focus for the fluorescent photomicrograph $(B)$ is on the bottom surface of the PC12 cells next to the substrate (no immunohistochemical staining was detected on the top surface of cells).

sistent with a role of $\mathrm{UPA}$ in changes in cell shape during mitosis and in motility (see Dano et al., 1985; Saksela and Rifkin, 1988). Involvement of UPA in both these events is suggested to result from changes in cell adhesion following the binding of uPA to specific receptors on focal contacts between the bottom surface of cells and the substratum (Pollanen et al., 1987, 1988; Hebert and Baker, 1988). The mechanism responsible for changes in cell adhesion has not been identified, although limited cleavages in cell surface components or components of the extracellular matrix are distinct possibilities. uPA may also be the initiating factor in a proteolytic cascade consisting of UPA, plasminogen, and procollagenase that degrades components of the extracellular matrix (Werb et al., 1977; Mignatti et al., 1986). This cascade of proteolytic activity may serve important functions during morphogenesis, tissue repair, and movement of migrating and malignant cells (see Dano et al., 1985; Saksela and Rifkin, 1988). tPA is released from endothelial cells during physical exercise or local stress reactions of the vasculature when clots and microemboli are present. The tPA binds to the fibrin clot and activates plasminogen, which then dissolves the clot. No other function has been ascribed to tPA; however, it is clear from the large number of tissues and cell types containing tPA (Danglot et al., 1986) that it is likely to be involved in other noncardiovascular functions. The nervous system and neuroen-

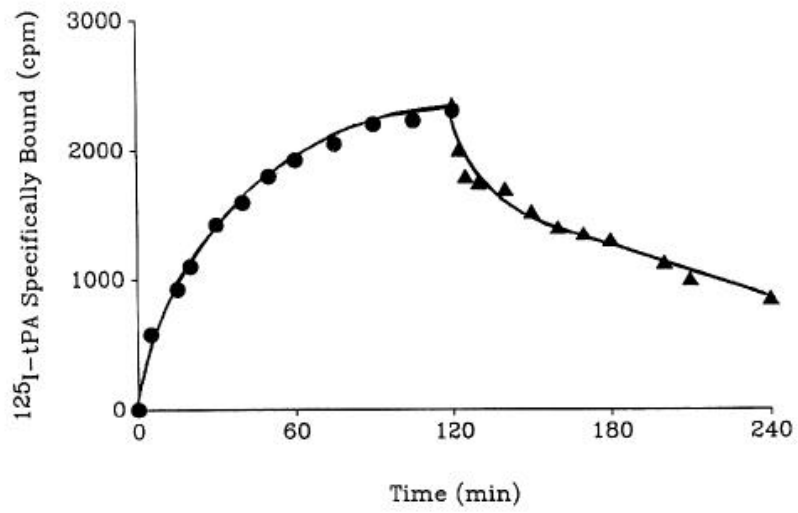

Figure 15. Reversible binding of ${ }^{125} \mathrm{I}$-tPA to sympathetic neurons. Sympathetic neurons were incubated with $15 \mathrm{nM}^{125} \mathrm{I}$-tPA for varying lengths of time at $22^{\circ} \mathrm{C}(\bullet)$. After $120 \mathrm{~min},{ }^{125} \mathrm{I}$-tPA was removed from some wells and $1.5 \mu \mathrm{M}$ unlabeled tPA added to the wells $(\boldsymbol{\Delta})$ to demonstrate the reversibility of the binding of ${ }^{125}$ I-tPA to the neurons.

drocrine tissues in particular have high concentrations of tPA (Kristensen et al., 1985, 1987; Danglot et al., 1986). A current speculation is that tPA may be involved in processing of peptide precursors in these tissues (Kristensen et al., 1985, 1987; Saksela and Rifkin, 1988), although at present there is no evidence to support this speculation.

Experiments in the present study indicate that even in the absence of plasminogen (immunological and biochemical studies indicate that plasminogen is not present in our cultures), PA appears to be involved in neurite outgrowth. Previous studies have shown that inhibition of serine proteases increases neurite outgrowth from neuroblastoma cells (Monard et al., 1983) and mouse sensory ganglia (Hawkins and Seeds, 1986). There is suggestive evidence in these studies that a thrombin-like protease and not a PA is being inhibited. However, for primary cultures of rat sympathetic neurons it appears that PA and not a thrombin-like protease is somehow involved in neurite outgrowth (Fig. 3). Inhibition of PA but not other serine proteases (e.g., plasmin and thrombin, Fig. 3; chymotrypsin and trypsin, data not shown) correlates with the increase in neurite outgrowth.

Both UPA and TPA appear to be released by sympathetic neurons (Fig. 4), although their release appears to be differentially regulated. Most of the neuronal uPA appears to be released as soon as it is synthesized and very little is associated with the neurons (either intracellularly or on the cell surface). This supposition is based on the large amount of uPA proteolytic activity present in the culture medium compared to cell-associated activity (Pittman, 1985a) and our inability to detect intracellular uPA immunoreactivity (unpublished observations) although we can detect some cell-surface-bound uPA (Fig. 14). tPA appears to be located primarily intracellularly and very little proteolytic activity is detected in the culture medium (Fig. 4). It is not even clear that the small amount of IPA proteolytic activity detected in the medium during the first several days in culture is being released by neurons. A small number of non-neuronal cells are also present in these cultures (ca. $5 \%$ of the total cells) during the first several days, and these non-neuronal cells may be the source of the tPA present in the culture medium. tPA immunoreactivity is present inside sympathetic neurons throughout the culture period and cell-surface-bound tPA can be detected in some cultures of sympathetic neurons. Often only a small 


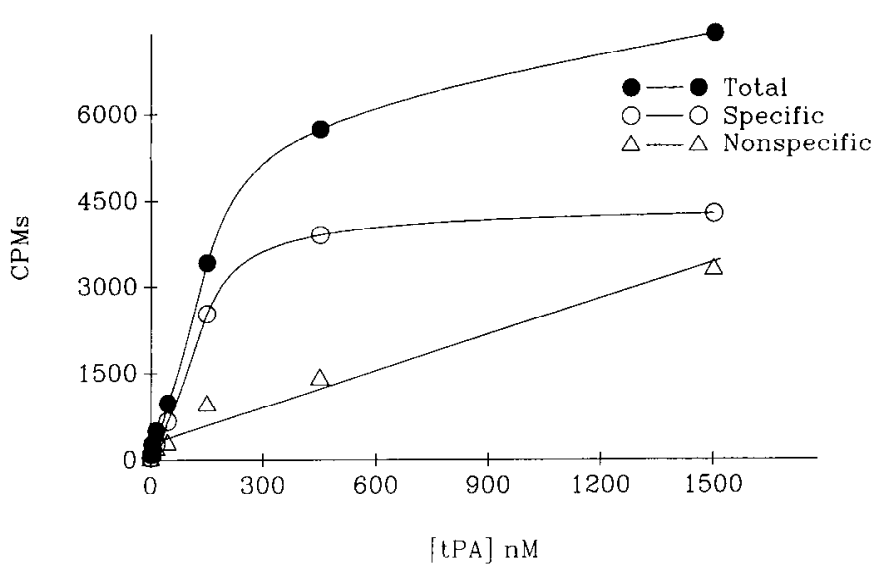

Figure 16. Saturation isotherms for binding ${ }^{125}$ I-tPA to sympathetic neurons. Sympathetic neurons were incubated with different concentrations of ${ }^{125} \mathrm{I}-\mathrm{tPA}$ in the absence or presence of $1.5 \mu \mathrm{M}$ unlabeled tPA. Total binding represents the amount of binding in the absence of unlabeled tPA and nonspecific binding is the amount of binding in the presence of unlabeled tPA. Specific binding is determined by subtracting nonspecific binding from total binding.

amount of tPA is present on the surface of neurons, whereas a large amount of tPA immunoreactivity is present intracellularly. The factor(s) responsible for regulating the release of tPA are at present unknown, but once identified may provide insights into the function of tPA.

Equally good correlations exist for inhibiting uPA or tPA proteolytic activity and increasing neurite outgrowth (Fig. 3). An affinity-purified antiserum that binds at or near the active site of uPA and inhibits its activity increases neurite outgrowth (Fig. 5). It appears, therefore, that UPA rather than tPA is involved in neurite outgrowth. However, antiserum that completely inhibits uPA activity increases neurite outgrowth only $60 \%$ as much as inhibitors like GGA (75\% increase in outgrowth with antiserum vs $130 \%$ increase with GGA). This may indicate that neurite outgrowth involves other PA-like proteolytic activities (e.g., tPA) or that GGA more effectively inhibits surfacebound uPA.

Most but not all neurites increase their rate of growth following inhibition of PA. In general, the greatest increases occur for neurites with slow rates of outgrowth (Fig. 8). Prior to addition of GGA, outgrowth rates average $32 \pm 11 \mu \mathrm{m} / \mathrm{hr}$, whereas during the first hour following exposure to GGA, neurite outgrowth rates average $78 \pm 17 \mu \mathrm{m} / \mathrm{hr}$. This increase in rate $(160 \%)$ is somewhat greater than is predicted from measurements taken from fixed cultures after $14-16 \mathrm{hr}(120-130 \%$ increase; Figs. 1, 2). The most likely explanation for this is that GGA oxidizes during the incubation at $37^{\circ} \mathrm{C}$ and that effective concentrations are not maintained for the full 14-16 hr. Support for this comes from preliminary experiments indicating that greater increases in outgrowth occur when GGA is given every $6 \mathrm{hr}$ rather than at a single time. Rates of neurite outgrowth obtained in videomicroscopy experiments (Fig. 8) predict a 2-3-fold greater length of neurites for both control and GGA-treated cultures than is observed following 14-hr experiments (Figs. 1, 2). Three factors are responsible for this apparent discrepancy: (1) Neurites are not "growing" for $14 \mathrm{hr}$ but rather are growing for $1-12 \mathrm{hr}$, because it takes time for the neurons to settle, attach, and initiate processes. Under conditions of the present experiment, the peak of neurite initiation occurs around $6 \mathrm{hr}$ after plating; therefore, the bulk of the neurites grow for $8 \mathrm{hr}$ rather than $14 \mathrm{hr}$. (2)

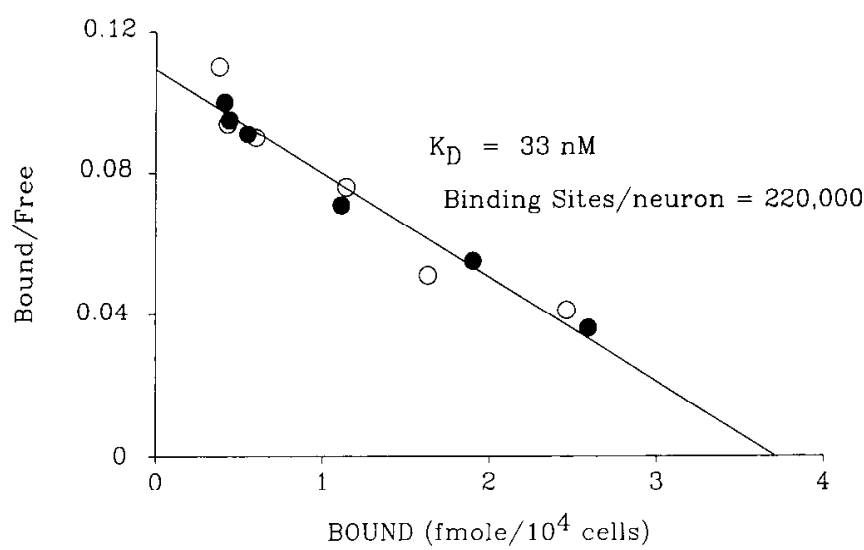

Figure 17. Scatchard plot of ${ }^{125}$ I-tPA binding to sympathetic neurons. Data for specific binding were taken from saturation isotherms (similar to those in Fig. 16) for neurons incubated with 125I-tPA in the absence (O) or presence (O) of $2 \mathrm{~mm} \mathrm{DFP} \mathrm{(an} \mathrm{irreversible} \mathrm{inhibitor}$ of the active site of IPA).

Early-initiating neurites (such as the ones observed in videomicroscopy experiments) tend to grow faster than later-initiating neurites (unpublished observations) and, because of the faster rate of growth and the longer period of outgrowth, tend to be much longer than later-initiating neurites. (3) Longer neurites are more likely to interact with other neurons or non-neuronal cells and therefore to be excluded from data analysis. This tends to "skew" data for 14-hr experiments toward shorter neurites that do not interact with other cells. Neurites in videomicroscopy experiments were chosen such that the chance of encountering another cell type was minimized.

\section{Cell surface binding sites for $P A$}

The purpose of the 3 binding sites for PA is unknown and one can only speculate as to their functions. Two of the binding sites have receptor-like properties and the other binding site appears to be a cell-associated protease inhibitor. Protease inhibitors are present on a large number of cell types (Eaton and Baker, 1983; Erickson et al., 1985; Guenther et al., 1985; Pittman and Patterson, 1987); therefore, it is not surprising that neurons also have an inhibitor associated with them. The most likely function for this $50-\mathrm{kDa}$ inhibitor is that it serves as a protective mechanism for the neuron during normal and/or pathological events in which large amounts of serine proteases are present in the local environment. A more specific example of this general role of inhibiting serine proteases is that the inhibitor may be localized to specific areas of the neuron required for stable adhesion to the substrate or stable cell/cell contacts. The inhibitor would help maintain stable contacts by inactivating PA released by the neuron and/or serine proteases present in the local environment. The inhibitor also appears to bind to heparan sulfate proteoglycan present on the neuronal surface. Therefore, it may participate in cell-cell or cell-substrate interactions by modulating the binding of surface proteoglycans and components of the extracellular matrix or other cells.

Immunohistochemical localization of cell surface bound uPA in the presence of DFP (to block binding to the inhibitor) indicates that uPA is present in patches on the bottom surface of PC12 cells (Fig. 14). uPA is also distributed in patches on the bottom surface of motile fibroblasts (Pollanen et al., 1987; Hebert and Baker, 1988). Nonmotile, quiescent fibroblasts lose this 
Figure 18. Immunohistochemical localization of ${ }^{125} \mathrm{I}$-tPA bound to cultures of sympathetic neurons. Sympathetic neurons were incubated with $15 \mathrm{nM}^{125}$ I-tPA $(A$ and $B$ ) or BSA $(C)$ for $2 \mathrm{hr}$ at $22^{\circ} \mathrm{C}$, washed, fixed with paraformaldehyde, and processed for HRP immunohistochemistry using mAb 6-17 (specific for human tPA). $A$ and $B$ provide a visual representation of where ${ }^{125}$ I-tPA is binding in these cultures. Note that the binding is to the neuronal cell bodies and neurites, but not to the laminin substrate. $B$ is a higher magnification view of neurite staining shown in $A$. $C$, representing the control, was overexposed so that cell bodies could be seen in bright-field illumination. The calibration bar in $B$ is $10 \mu \mathrm{m}$, and in $C$ is $40 \mu \mathrm{m} \mathrm{(} A$ is at the same magnification as $C$ ).
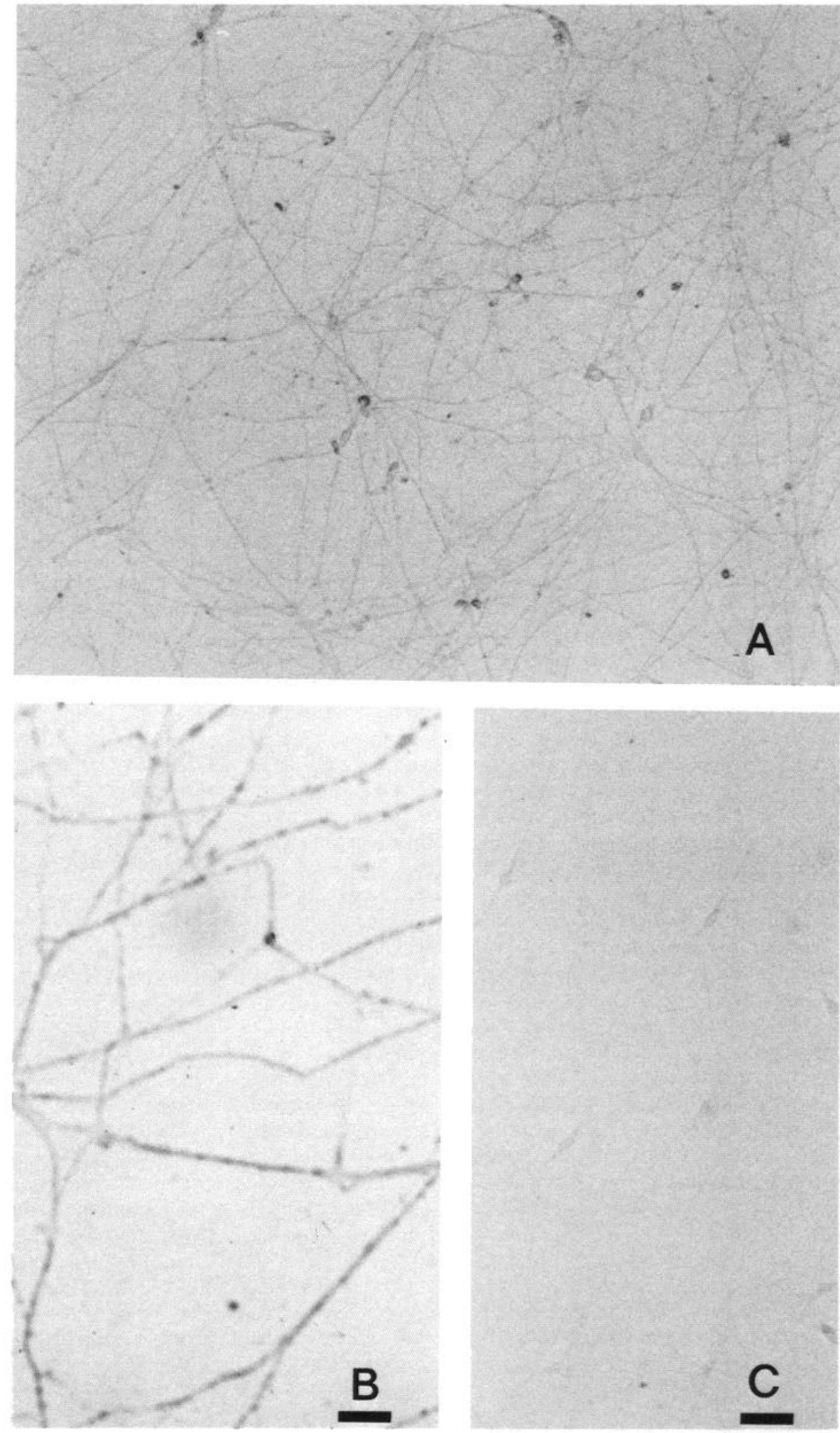

"patchy" distribution of uPA binding on their bottom surfaces (Pollanen et al., 1988). Electron microscopic localization of surface bound uPA on motile fibroblasts indicates that it is present on the bottom surface of focal adhesion plaques (Pollanen et al., 1988). Focal adhesion plaques in motile cells are transient contact points between the cell membrane and the substratum (Couchman and Rees, 1979; Burridge and Connell, 1983) and are considered to be involved in motility. A possible function for the neuronal binding site selective for uPA is that it localizes uPA in a proteolytically active form at focal contacts so that 


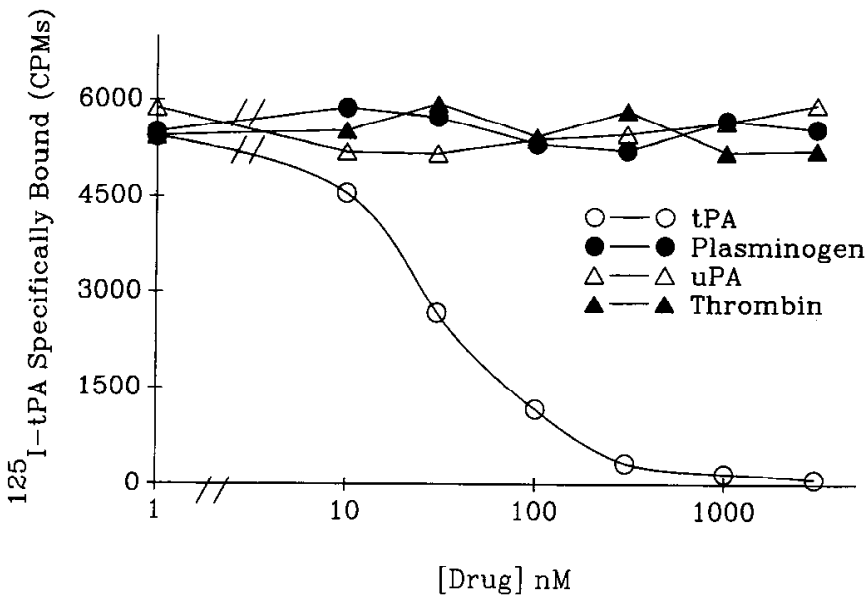

Figure 19. Binding of ${ }^{125}$ I-tPA to sympathetic neurons in the presence of various concentrations of serine proteases. Binding of ${ }^{125} \mathrm{I}$ tPA $(20 \mathrm{nM})$ was carried out in the presence of the indicated concentrations of uPA, plasminogen, thrombin, or unlabeled tPA. Specific binding was determined in the presence of $1.5 \mu \mathrm{M}$ unlabeled tPA.

uPA can help make and/or break adhesive contacts during neurite outgrowth. The "spots" and patches of proteolytically active PA that remain on the substratum following removal of neurons (Krystosek and Seeds, 1986; Pittman, unpublished observations) may represent uPA associated with these binding sites on focal contacts.

Sympathetic neurons have over 300,000 high-affinity tPAselective binding sites on their surface. A number of other cell types have also been reported to contain tPA binding sites, including fibroblasts (Hoal et al., 1983; Hajjar et al., 1987), endothelial cells (Beebe, 1987; Hajjar et al., 1987; Barnathan et al., 1988), and granule neurons of the cerebellum (Verrall and Seeds, 1988). Initial characterization of the binding site for tPA on cerebellar granule neurons indicates that its properties are different from those of the binding site present on sympathetic neurons. Pharmacological characterization of the binding site on granule neurons has not been reported; however, fibrinolysis assays (Verrall and Seeds, 1988) indicate that the binding site on granule neurons appears to have a higher affinity for tPA than the binding site on sympathetic neurons $(250 \mathrm{mIU}$, or about $1 \mathrm{ng}$, binds very efficiently to granule neurons - this is a 100-1000-fold lower concentration than is needed to bind to sympathetic neurons). Some of the cellular binding sites reported for tPA appear to bind at the active site of tPA (Hoal et al., 1983; Barnathan et al., 1988), and therefore are more similar to the inhibitor that we have characterized on sympathetic neurons and PC12 cells (Figs. 9-13; and Appendix). The binding sites with pharmacological properties most similar to those of the "receptor-like" tPA-selective binding site on sympathetic neurons are the binding sites on human umbilical vein endothelial cells and fibroblasts (Hajjar et al., 1987). These binding sites have $K_{\mathrm{D}}$ values of 10-20 nM for ${ }^{125}$ I-tPA and 400,000-800,000 binding sites/cell, compared to a $K_{\mathrm{D}}$ value of $20 \mathrm{nM}$ and 300,000 sites/cell for the binding site on sympathetic neurons.

As is the case for these other tPA binding sites, the function of the neuronal binding site for IPA is unknown. tPA bound to this site on the neuronal surface, however, would be in an ideal position for altering ncurite outgrowth dynamics, for activating zymogens (e.g., plasminogen) in the local environment of the growing neurite, and for degrading molecules associated with the extracellular matrix, glia, or target cells. It is also possible that tPA serves as a ligand for its cell surface receptor and acts on the neuron in an autocrine and/or paracrine-like manner to produce secondary biochemical changes. The serine protease thrombin binds to specific cell surface reccptors on platelets and other cell types and produces a number of secondary biochemical events, including release of prostacycline and arachidonic acid, increased phosphoinositol turnover, alterations in protein phosphorylation, and release of aggregating and chemotactic agents (Billah and Lapetina, 1982; Agranoff et al., 1983; Chambard and Pouyssegur, 1983; Prescott et al., 1984; Carney, 1987).

\section{Involvement of $P A$ in neurite outgrowth}

Key questions concerning PA activity and its relationship to neurite outgrowth are: (1) What is the most likely site for inhibition of PA that results in an increase in neurite outgrowth? (2) What mechanism could account for this increase in neurite outgrowth? A trivial explanation for why inhibitors increase neurite outgrowth is that proteases released by the neurons decrease adhesion in a nonspecific manner, much the same way that low levels of trypsin in the medium would decrease adhesion. Inhibitors of serine proteases would increase neurite outgrowth by inhibiting this nonspecific proteolytic activity and enabling neurons to stick to the substrate more effectively. The increase in neurite outgrowth did not correlate with general serine proteases with broad substrate activity (plasmin, thrombin-Fig. 3; trypsin or chymotrypsin-data not shown); instead the increase correlated specifically with PA activity. Incubation of radiolabeled neurons and/or ECM from neuronal cultures with PA does not alter the position of any proteins detected following 2-dimensional gel electrophoresis and autoradiography (unpublished observations), suggesting that PA is not having a general "proteolytic" effect on these cultures. Of all protein substrates tested, only 3 (plasminogen, fibronectin, and a 66$\mathrm{kDa}$ protein) have been found to be cleaved by PAs. Plasminogen is not present in our cultures, and the plasmin-specific inhibitor aprotinin does not affect neurite outgrowth. Neurons are grown on a laminin substrate, so if small quantities of fibronectin are produced by the neurons, it probably has little or no effect on adhesion or outgrowth relative to the contribution made by laminin. The $66-\mathrm{kDa}$ protein present in the pericellular matrix of fibroblasts that appears to be cleaved by uPA may be involved in the effects of inhibitors on neurite outgrowth. However, it is clear that PAs are not having a "trypsin-like" effect on neuronal adhesion and that this is responsible for the effects of inhibitors on neurite outgrowth.

Based on the increase in outgrowth produced by antiserum that inhibits uPA activity (Fig. 5) and on the possibility that cell-associated uPA is present on transient structures (focal contacts) felt to be involved in motility (Pollanen et al., 1988), it would seem that the most likely site for inhibition of PA leading to an increase in neurite outgrowth is inhibition of UPA at its cellular binding site. A variety of mechanisms can account for the increase in outgrowth following inhibition of PA. The simplest hypothesis is that inhibitors of PA increase neurite outgrowth by increasing the adhesion of the growth cone to the substrate. For example, uPA may be one of several factors involved in the deadhesion of the base of the growth cone (next to the neurite) which results in "collapsing" of the base of the growth cone to form the neurite. uPA would do this by binding to receptors on focal adhesion plaques over the entire bottom 
surface of the growth cone. As new focal adhesion plaques form near the leading edge of the growth cone, old plaques would "move" toward the base of the growth cone. During this transition of adhesion plaques from the leading edge to the base of the growth cone, uPA would decrease the adhesion between focal adhesion plaques and the substrate by producing a limited number of cleavages in cell surface or matrix components. Inhibitors would block these cleavages and increase adhesion of the growth cone to the substrate. This increased adhesion of the growth cone to the substrate may decrease the amount of backward "slippage" or retraction of the growth cone (see Argiro et al., 1984; Katz, 1985; Bray and Hollenbeck, 1988) and produce an increased rate of forward outgrowth.

Membrane ruffling and activity along the sides and base of growth cones may reflect the progressive loss or decreased binding of adhesion plaques to the substrate. The observation that there is a decrease in activity on the sides and base of the growth cone (Fig. 7) following inhibition of PA with GGA is consistent with, but clearly does not prove, the "uPA/adhesion plaque" hypothesis presented above. It is equally likely that the decreased membrane activity on the sides of the growth cones and increased activity at the leading edge may be an epiphenomenon of the increased rate of outgrowth.

A variety of other hypotheses could account for the increase in neurite outgrowth following inhibition of PA, including differential distribution of $\mathrm{uPA}$ receptors on the leading edge compared to other parts of the growth cone and involvement of the uPA-receptor complex in various adhesion and/or deadhesion events. All 3 binding sites described in the present study as well as other undefined PA-dependent functions may be involved in neurite outgrowth in vivo. Clearly, tPA present on the cell surface could activate plasminogen if it is present in the local environment and help degrade components of the extracellular matrix during neurite outgrowth. In addition, modulation of intracellular second messengers by UPA and/or tPA binding to cell surface receptors could also account for increases in neurite outgrowth following inhibition of PA (see Kater et al., 1988; Mattson et al., 1988, for effects of second-messenger systems on neurite outgrowth).

In summary, these data provide evidence for a role for neuronal PA in neurite outgrowth. The mechanism of action of PA is unknown but may involve cell surface binding sites for uPA and/or tPA. Key to understanding the role of PA in development and neurite outgrowth is the need to purify and/or clone rat uPA, identify factors that regulate tPA release, characterize the receptors for $\mathrm{UPA}$ and $\mathrm{PPA}$, and determine the effects of neurite/ target cell interactions on PA (activity, protein, and mRNA).

\section{Appendix}

Binding sites for PA on the surface of neurons

Inhibitor

Not an integral membrane protein

Binds to heparinase-sensitive site on the surface

$M_{\mathrm{r}} 50 \mathrm{kDa}$

Forms a $68-\mathrm{kDa}$ complex with the active site of $\mathrm{uPA}$

Binds serine proteases of several species

Saturated with uPA in our cultures

\section{UPA-selective binding site}

Punctate patches of UPA on the bottom surface of PC12 cells

Binds to a part of UPA distinct from the active site

Species specific (does not bind human uPA)

Probably saturated in our cultures

\section{tPA-selective binding site}

Surface-bound tPA homogeneously distributed

Binds to a part of tPA distinct from the active site

Not species specific (binds human tPA)

tPA selective (does not bind other serine proteases)

$K_{\mathrm{D}}=23 \pm 10 \mathrm{nM}$ for ${ }^{125} \mathrm{I}$-tPA (human)

$340,000 \pm 130,000$ sites/neuron

Routinely $<10 \%$ saturated in our cultures

\section{References}

Agranoff, B. W., P. Murthy, and E. B. Seguin (1983) Thrombin-induced phosphodiesteratic cleavage of phosphatidylinositol bisphosphate in human platelets. J. Biol. Chem. 258: 2076-2078.

Alvarez-Buylla, A., and J. E. Valinsky (1985) Production of plasminogen activator in cultures of superior cervical ganglia and isolated Schwann cells. Proc. Natl. Acad. Sci. USA 82: 3519-3523.

Argiro, V., M. B. Bunge, and M. I. Johnson (1984) Correlation between growth form and movement and their dependence on neuronal age. J. Neurosci. 4: 3051-3062.

Barnathan, E. S., A. Kuo, H. Van der Keyl, K. R. McCrai, G. R. Larsen, and D. B. Cines (1988) Tissue-type plasminogen activator binding to human endothelial cells: Evidence for two distinct binding sites. J. Biol. Chem. 263: 7792-7799.

Baxter, D. A., D. Johnston, and W. J. Strittmatter (1983) Protease inhibitors implicate metalloendoprotease in synaptic transmission at the mammalian neuromuscular junction. Proc. Natl. Acad. Sci. USA 80:4174-4178.

Beckerle, M. C., K. Burridge, G. N. DeMartino, and D. E. Croall (1987) Colocalization of calcium-dependent protease II and one of its substrates at sites of cell adhesion. Cell 51: 569-577.

Beebe, D. P. (1987) Binding of tissue plasminogen activator to human umbilical vein endothelial cells. Thromb. Res. 46: 241-254.

Billah, M. M., and E. G. Lapetina (1982) Formation of lysophosphatidylinositol in platelets stimulated with thrombin or ionophore A23187. J. Biol. Chem. 257: 5196-5200.

Bottenstein, J. E., S. D. Skaper, S. S. Varon, and G. H. Sato (1980) Selcctive survival of neurons from chick embryo sensory ganglionic dissociates utilizing serum-free supplemented medium. Exp. Cell Res. 125: $183-190$.

Bray, D., and P. J. Hollenbeck (1988) Growth cone motility and guidance. Annu. Rev. Cell Biol. 4: 43-62.

Burridge, K., and L. Connell (1983) A new protein of adhesion plaques and ruffling membranes. J. Cell Biol. 97: 359-367.

Burridge, K., and P. Mangeat (1984) An interaction between vinculin and talin. Nature 308: 744-745.

Burton, L. E., W. H. Wilson, and E. M. Shooter (1978) Nerve growth factor in mouse saliva. Rapid isolation procedures for characterization of 7s nerve growth factor. J. Biol. Chem. 253: 7807-7812.

Carney, D. H. (1987) Perspectives on the cellular and biochemical effects of thrombin interaction with surface receptors and substrate molecules. In Proteases in Biological Control and Biotechnology, D. D. Cunningham and G. L. Long, eds., pp. 277-282, Liss, New York.

Carney, D. H., and D. D. Cunningham (1977) Initiation of chick cell division by trypsin action at the cell surface. Nature 268: 602-606.

Chambard, J. C., and J. Pouyssegur (1983) Thrombin-induced protein phosphorylation in resting platelets and fibroblasts: Evidence for common post-receptor molecular events. Biochem. Biophys. Res. Commun. 111: 1034-1044.

Chandra, S., and N. U. Bang (1977) Analysis of primary and secondary complexes between antithrombin III, thrombin, and factor $\mathrm{Xa}$. In Chemistry and Biology of Thrombin, R. L. Lundblad, J. W. Fenton II, and K. G. Mann, eds., pp. 421-429, Ann Arbor Science, Ann Arbor, MI.

Chen, L. B., and J. M. Buchanan (1975) Mitogenic activity of blood components. I. Thrombin and prothrombin. Proc. Natl. Acad. Sci. USA 72: 131-135.

Cook, K. S., D. L. Groves, H. Y. Min, and B. M. Spiegelman (1987) Differentiation-dependent expression in 3T3 adipocytes of a mRNA encoding a novel protein related to serine proteases. J. Cell Biol. Abstr. 105: 6147.

Couchman, J. R., and D. A. Rees (1979) The behaviour of fibroblasts migrating from chick heart explants: Changes in adhesion, locomotion and growth, and the distribution of actonyosin and fibronectin. J. Cell Sci. 39: 149-165. 
Danglot, G., D. Vinson, and F. Chapeville (1986) Qualitative and quantitative distribution of plasminogen activators in organs from healthy adult mice. FEBS Lett. 194: 96-100.

Dano, K., P. A. Andreasen, J. Grondahl-Hansen, B. Kristensen, L. S. Nielsen, and L. Skriver (1985) Plasminogen activators, tissue degradation and cancer. Adv. Cancer Res. 44: 146-239.

DeLotto, R., and P. Spierer (1986) A gene required for the specification of dorsal-ventral pattern in Drosophila appears to encode a serine protease. Nature 323: 688-692.

Deutsch, D. G., and E. T. Mertz (1970) Plasminogen: Purification from human plasma by affinity chromatography. Science $170: 1095$ 1096.

Dunn, G. A. (1983) Characterising a kinesis response: Time averaged measures of cell speed and directional persistence. Agents Actions 12 . 14-33.

Eaton, D. L., and J. B. Baker (1983) Evidence that a variety of cultured cells secrete protease nexin and produce a distinct cytoplasmic serine protease-binding factor. J. Cell. Physiol. 117: 175-182.

Erickson, L. A., C. M. Kekman, and D. J. Loskutoff (1985) The primary plasminogen-activator inhibitors in endothelial cells, platelets, serum, and plasma are immunologically related. Proc. Natl. Acad. Sci. USA 82: 8710-8714.

Glass, R. H., J. Aggeler, A. Spindle, R. A. Pendersen, and Z. Werb (1983) Degradation of extracellular matrix by mouse trophoblast outgrowth: A model for implantation. J. Cell Biol. 96: 1108-1116.

Greene, L. A., and A. S. Tischler (1976) Establishment of a noradrenergic clonal cell line of rat adrenal pheochromocytoma cells which respond to nerve growth factor. Proc. Natl. Acad. Sci. USA 73: 2424 2428.

Grossman, G., J. P. Quigley, and J. E. Valinsky (1987) An antibody with anti-catalytic activity against chicken plasminogen activator inhibits neural crest cell migration in vitro. J. Cell Biol. Abstr. 105: 1256.

Guenther, J., N. Hanspeter, and D. Monard (1985) A glia-derived neurite promoting factor with protease inhibitory activity. EMBO J. 4: $1963-1966$.

Gurwitz, D., and D. D. Cunningham (1988) Thrombin modulates and reverses neuroblastoma neurite outgrowth. Proc. Natl. Acad. Sci. USA 85: 3440-3444

Hajjar, K. A., N. M. Hamel, P. C. Harpel, and R. L. Nachman (1987) Binding of tissue plasminogen activator to cultured human endothelial cells. J. Clin. Invest. 80: 1712-1719.

Hawkins, R. L., and N. W. Seeds (1986) Effect of proteases and their inhibitors on neurite outgrowth from neonatal mouse sensory ganglia in culture. Br. Res. 398: 63-70.

Hawrot, E., and P. H. Patterson (1979) Long-term culture of dissociated sympathetic neurons. Methods Enzymol. 58: 574-584.

Hebert, C. A., and J. B. Baker (1988) Linkage of extracellular plasminogen activator to the fibroblast cytoskeleton: Colocalization of cell surface urokinase with vinculin. J. Cell Biol. 106: 1241-1247.

Hoal, E. G., E. L. Wilson, and E. B. Dowdle (1983) The regulation of tissue plasminogen activator activity by hyman fibroblasts. Cell 34 : 273-279.

Horwitz, A., K. Duggan, R. Greggs, C. Decker, and C. Buck (1985) The cell-substrate attachment (CSAT) antigen has properties of a receptor for laminin and fibronectin. J. Cell Biol. 101: 2134-2144.

Ivins, J. K., P. Midgette, and R. N. Pittman (1987) Characterization of a neuronal serine protease whose inhibition alters neurite outgrowth. Soc. Neurosci. Abstr. 13: 414.13.

Johnson, D. H., and J. Travis (1976) Human alpha-1-proteinase inhibitor mechanism of action by limited proteolysis. Biochem. Biophys. Res. Commun. 72: 33-39.

Kalderon, N. (1984) Schwann cell proliferation and localized proteolysis: Expression of plasminogen-activator activity predominates in the proliferating cell populations. Proc. Natl. Acad. Sci. USA 81: 72167220.

Kater, S. B., M. P. Mattson, C. Cohan, and J. Connor (1988) Calcium regulation of the neuronal growth cone. Trends Neurosci. 11:315321 .

Katz, M. J. (1985) How straight do axons grow? J. Neurosci. 5: 589595.

Keski-Oja, I., and A. Vaheri (1982) The cellular target for the plasminogen activator, urokinase, in human fibroblasts-66000-dalton pmtein. Biochem. Biophys. Acta 720: 141-146.

Kristensen, P., J. S. Nielsen, J. Grondahl-Hansen, P. B. Andresen, L.-
I. Larsson, and K. Dano (1985) Immunocytochemical demonstration of tissue-type plasminogen activator in endocrine cells of the rat pituitary gland. J. Cell Biol. 101: 305-311.

Kristensen, P., J. S. Nielsen, L.-I. Larsson, and K. Dano (1987) Tissuetype plasminogen activator in somatostatin cells of rat pancreas and hypothalamus. Endocrinology $121: 2238-2244$.

Krystosek, A., and N. W. Seeds (1981a) Plasminogen activator secretion by granule neurons in cultures of developing cerebellum. Proc. Natl. Acad. Sci. USA 78: 7810-7814.

Krystosek, A., and N. W. Seeds (1981b) Plasminogen activator release at the neuronal growth cone. Science 213: 1532-1534.

Krystosek, A., and N. W. Seeds (1984) Peripheral neurons and Schwann cells secrete plasminogen activator. J. Cell Biol. 98: 773-776.

Krystosek, A., and N. W. Seeds (1986) Normal and malignant cells, including neurons, deposit plasminogen activator on the growth substrata. Exp. Cell Res. 166: 31-46.

Laemmli, U. K. (1970) Cleavage of structural proteins during the assembly of the head of bacteriophage T4. Nature 227: 680-681.

Lynch, G., and M. Baudry (1984) The biochemistry of memory: A new and specific hypothesis. Science 224: 1057-1063.

Mattson, M. P., A. Taylor-Hunter, and S. B. Kater (1988) Neurite outgrowth in individual neurons of a neuronal population is differentially regulated by calcium and cyclic AMP. J. Neurosci. 8: 1704 1711.

Mignatti, P., E. Robbins, and D. B. Rifkin (1986) Tumor invasion through the human amniotic membrane: Requirement for a proteinase cascade. Cell 47: 487-498.

Monard, D. (1988) Cell-derived proteases and protease inhibitors as regulators of neurite outgrowth. Trends Neurosci. 11: 541-544.

Monard, D., E. Miday, A. Limat, and F. Solomon (1983) Inhibition of protease activity can lead to neurite extension in neuroblastoma cells. Prog. Brain Res. 58: 359-364.

Moonen, G., M.-P. Grau-Wagemans, and I. Selak (1982) Plasminogen activator-plasmin system and neuronal migration. Nature 298: 753755.

Moonen, G., M.-P. Grau-Wagemans, I. Selak, Ph. P. Lefebvre, B. Rogister, J. D. Vassalli, and D. Belin (1985) Plasminogen activator is a mitogen for astrocytes in developing cerebellum. Dev. Br. Res. 20: $41-48$.

Ortolani, G., E. Patricolo, and C. Mansueto (1979) Trypsin-induced cell surface changes in ascidian embryonic cells. Exp. Cell Res. 122: 137-147.

Pittman, R. N. (1985a) Release of plasminogen activator and a calcium-dependent metalloprotease from cultured sympathetic and sensory neurons. Dev. Biol. 110: 91-101.

Pittman, R. N. (1985b) Characterization of a neuronal protein that binds plasminogen activator. Soc. Neurosci. Abstr. 11 : 221.4.

Pittman, R. N. (1988) Cell surface binding sites for plasminogen activators. Soc. Neurosci. Abstr. 14: 240.9.

Pittman, R. N., and P. H. Patterson (1987) Characterization of an inhibitor of neuronal plasminogen activator released by heart cells. J. Neurosci. 7: 2664-2673.

Pittman, R. N., and A. G. Williams (1989) Neurite penetration into collagen gels requires $\mathrm{Ca}^{2+}$-dependent metalloproteinase activity. Dev. Neurosci. 11: 41-51.

Pollanen, J., O. Saksela, E.-M. Salonen, P. Andreasen, L. Nielsen, K. Dano, and A. Vaheri (1987) Distinct localizations of urokinase-type plasminogen activator and its type 1 inhibitor under cultured human fibroblasts and sarcoma cells. J. Cell Biol. 104: 1085-1096.

Pollanen, J., K. Hedman, L. S. Nielsen, K. Dano, and A. Vaheri (1988) Ultrastructural localization of plasma membrane-associated urokinase-type plasminogen activator at focal contacts. J. Cell Biol. 106: 87-95.

Prescott, S. M., G. A. Zimmerman, and T. M. McIntyre (1984) Human endothelial cells in culture produce platelet-activating factor (1-alkyl2-acetyl-sn-glycero-3-phosphocholine) when stimulated with thrombin. Proc. Natl. Acad. Sci. USA 81: 3534-3538.

Quigley, J. P., L. T. Gold, R. Schwimmer, and L. M. Sullivan (1987) Limited cleavage of cellular fibronectin by plasminogen activator purified from transformed cells. Proc. Natl. Acad. Sci. USA 84: 27762780.

Robbins, D. R., L. Summaria, B. Hsieh, and R. J. Shah (1967) The peptide chains of human plasmin. Mechanism of activation of human plasminogen to plasmin. J. Biol. Chem. 242: 2333-2342.

Saksela, O., and D. B. Rifkin (1988) Cell-associated plasminogen ac- 
tivation: Regulation and physiological functions. Annu. Rev. Cell Biol. 4: 93-126.

Salonen, E.-M., A. Zitting, and A. Vaheri (1984) Laminin interacts with plasminogen and its tissue-type activator. FEBS Lett. 172: 2932.

Scatchard, G. (1949) The attraction of proteins for small molecules and ions. Ann. NY Acad. Sci. 51: 600-672.

Scott, R. W., and J. B. Baker (1983) Purification of human protease nexin. J. Biol. Chem. 258: 10439-10444.

Soreq, H., and R. Miskin (1981) Plasminogen activator in the rodent brain. Br. Res. 216: 361-374.

Soreq, H., and R. Miskin (1983) Plasminogen activator in the developing rat cerebellum: Biosynthesis and localization in granular neurons. Br. Res. 313: 149-158.

Strickland, S., E. Reich, and M. I. Sherman (1976) Plasminogen activator in early embryogenesis: Enzyme production by trophoblast and parietal endoderm. Cell 9:231-240.

Umezawa, H., and T. Aoyagi (1977) Activities of proteinase inhibitors of microbial origin. In Proteinases in Mammalian Cells and Tissues, A. J. Barrett, ed., pp. 637-662, North-Holland, New York.
Valinsky, J. E., and N. M. LeDouarin (1985) The production of plasminogen activator by migrating cephalic neural crest cells. EMBO J. 4: 1403-1406.

Valinsky, J. E., E. Reich, and N. M. LeDouarin (1981) Plasminogen activator in the bursa of Fabricius. Correlations with morphogenetic remodeling and cell migrations. Cell 25: 471-476.

Verrall, S., and N. W. Seeds (1988) Tissue plasminogen activator binding to mouse cerebellar granule neurons. J. Neurosci. Res. 21: $420-425$.

Werb, Z., C. Mainardi, C. A. Vater, and E. D. Harris (1977) Endogenous activation of latent collagenase by rheumatoid synovial cells. Evidence for a role of plasminogen activator. N. Engl. J. Med. 296: 1017-1023.

Wun, T. C., L. Ossowski, and E. Reich (1982) A proenzyme form of human urokinase. J. Biol. Chem. 257: 262-268.

Zurn, A. D., H. Nick, and D. Monard (1988) A glia-derived nexin promotes neurite outgrowth in cultured chick sympathetic neurons. Dev. Neurosci. 10: 17-24. 